\title{
Imperfect Credibility and Inflation Persistence
}

\author{
Christopher J. Erceg* and Andrew T. Levin** \\ Federal Reserve Board \\ 20th and C Streets, N.W., Stop 42 \\ Washington, DC 20551 USA \\ First Version: July 2000 \\ Current Version: June 2001
}

\begin{abstract}
In this paper, we formulate a dynamic general equilibrium model with staggered nominal contracts, in which households and firms use optimal filtering to disentangle persistent and transitory shifts in the monetary policy rule. The calibrated model accounts quite well for the dynamics of output and inflation during the Volcker disinflation, and implies a sacrifice ratio very close to the estimated value. Our approach indicates that inflation persistence and substantial costs of disinflation can be generated in an optimizing-agent framework, without relaxing the assumption of rational expectations or relying on arbitrary modifications to the aggregate supply relation.
\end{abstract}

JEL classification: E31; E32; E52.

Keywords: Monetary policy, disinflation, sacrifice ratio, signal extraction.

* Corresponding Author: Telephone 202-452-2575, Fax 202-872-4926 Email christopher.erceg@frb.gov

** Telephone 202-452-3541, Fax 202-872-4926, Email andrew.levin@frb.gov 


\section{Introduction*}

Since the pioneering work of Taylor (1980) and Calvo (1983), business cycle dynamics and the role of monetary policy have been analyzed in models with staggered nominal contracts. In recent years, such contracts have been incorporated into dynamic general equilibrium (DGE) models derived from microeconomic foundations. ${ }^{1}$ Nevertheless, models with staggered contracts have been criticized for failing to generate a sufficient degree of inflation persistence and for implying unrealistically low costs of disinflation (Ball 1994; Fuhrer and Moore 1995). ${ }^{2}$

In this paper, we formulate a DGE model with optimizing agents and staggered nominal contracts, and we show that this model can generate inflation persistence and substantial output costs of disinflation when private agents have limited information about the central bank's objectives. ${ }^{3}$ In particular, households and firms use optimal filtering to disentangle persistent shifts in the inflation target from transitory disturbances to the monetary policy rule. Under these assumptions, the speed at which private agents recognize a new inflation target depends on the transparency and credibility of the central bank. Thus, the signal-to-noise ratio is the key parameter determining the persistence of inflation forecast errors, and hence influencing the persistence of actual inflation and output.

We show that this model can account quite well for the dynamics of output and inflation during the Volcker disinflation. Using data from the Survey of Professional Forecasters, we calibrate the signal-to-noise ratio to match the observed evolution of one-year-ahead inflation forecasts over the period 1980:4-1985:4. With four-quarter wage and price contracts and an empirically reasonable calibration of capital adjustment costs, the model implies output costs of about 1.6 percentage points for each percentage point reduction in the inflation rate; this sacrifice ratio is remarkably close to the estimated value for the Volcker disinflation.

Our analysis contrasts sharply with existing approaches for generating inflation persistence and substantial costs of disinflation. First, we avoid arbitrary departures

${ }^{*}$ We appreciate comments and suggestions from Larry Christiano, Mike Dotsey, Marty Eichenbaum, Charlie Evans, Marvin Goodfriend, Dale Henderson, Peter Ireland, Athanasios Orphanides, John Taylor, Alex Wolman, and participants in workshops at the July 2000 NBER Summer Institute, the Federal Reserve Board, the European Central Bank, and the Richmond Federal Reserve Bank. The views expressed in this paper are solely the responsibility of the authors and should not be interpreted as reflecting the views of the Board of Governors of the Federal Reserve System or of any other person associated with the Federal Reserve System.

${ }^{1}$ Lucas (1986) analysed a DGE model with staggered price contracts of fixed duration, while Levin (1989) analyzed a DGE model with staggered wage contracts of this type. For recent examples, see Rotemberg and Woodford (1997), King and Wolman (1999), and Erceg, Henderson, and Levin (2000).

${ }^{2}$ The same criticism applies to models with quadratic costs of price adjustment (cf. Rotemberg 1996; Kim 2000), which have similar first-order dynamic properties to models with staggered nominal contracts.

${ }^{3}$ Our approach is similar in spirit to that of Ball (1995), who used a small structural model to show that imperfect credibility can raise the output costs of disinflation, and to that of Ireland $(1995,1997)$, who analyzed optimal disinflation paths using a highly stylized DGE framework but did not focus on the quantitative implications. 
from the optimizing-agent framework, such as adding lagged inflation terms to the aggregate supply relation or imposing adaptive rather than rational expectations. ${ }^{4}$ Our assumption that agents process information efficiently is consistent with the findings of Evans and Wachtel (1993), who analyzed survey data on inflation expectations and demonstrated that persistent ex post forecast errors during the period 1968-85 should not be viewed as "irrational" but rather as reflecting the degree of uncertainty about the underlying inflation regime.

Second, our analysis implies that inflation persistence is not an inherent characteristic of the economy but rather varies with the stability and transparency of the monetary policy regime. As discussed below, this perspective is consistent with empirical evidence indicating very high U.S. inflation persistence (close to that of a random walk) during the period 1965-84 and much lower persistence during the remainder of the postwar period. In contrast, the empirical evidence appears to be inconsistent with models that incorporate inherent inflation persistence due to contract structure or adaptive expectations.

Finally, in our model, the costs of disinflation are radically diminished if agents quickly recognize the shift in the inflation target, whereas the learning rate is of relatively minor importance in models with inherent inflation persistence. ${ }^{5}$ More generally, our approach suggests that efforts to enhance transparency and credibility can facilitate the effectiveness of monetary stablilization policy.

The remainder of this paper is organized as follows. Section 2 reviews several important stylized facts, and highlights the credibility problems faced by the Federal Reserve during the Volcker disinflation. Section 3 presents our model, while Section 4 describes the calibration and solution methods. Section 5 investigates the model's simulated responses to a disinflation shock. Section 6 compares our approach to accounting for inflation persistence to the previous literature. Section 7 provides conclusions and suggests directions for future research.

\section{Key Stylized Facts}

In this section, we briefly characterize the persistence properties of postwar U.S. inflation, and then we highlight several key aspects of the Volcker disinflation. We interpret large and persistent inflation forecast errors as largely attributable to the Federal Reserve's lack of credibility following the unstable policies of the 1970s and the early abandonment of the initial monetary tightening of October 1979.

\footnotetext{
${ }^{4}$ See the discussion in Clarida, Gali, and Gertler (1999). For example, Fuhrer and Moore (1995) obtained substantial costs of disinflation using an estimated version of the overlapping relative real wage contract specification of Buiter and Jewitt (1981), but that specification is inconsistent with standard micro-founded models of wage and price determination (cf. Roberts 1997). An alternative approach is to assume that some private agents have adaptive expectations; cf. Roberts (1998, 2001), Ball (2000), and Ireland (2000).

${ }^{5}$ In models with intrinsic inflation persistence, Bomfim et al. (1997) and Huh and Lansing (2000) find that the credibility of the central bank has relatively small effects on the costs of disinflation.
} 


\subsection{The Dynamic Properties of U.S. Inflation}

Figure 1 depicts the postwar evolution of the U.S. GDP price inflation rate (that is, the annualized one-quarter inflation rate of the chain-weighted GDP price deflator). From this figure, it is apparent that inflation exhibited relatively high persistence between the mid-1960s and mid-1980s: annual average inflation rose progressively from 2 percent to around 10 percent in 1980, and then fell to about 4 percent by the end of the Volcker disinflation. Our analysis focuses on explaining the dynamics of inflation during the latter period, while leaving an explanation of the 1965-79 period to future research. ${ }^{6}$

Interestingly, while U.S. inflation appears to have followed a random walk over roughly the 1965-84 period, the inflation rate exhibits much less persistence prior to 1965 and after about 1984. These shifts in inflation persistence have been documented using several different econometric approaches. For example, Taylor (2000) found that the largest autoregressive root of inflation has a 95 percent confidence interval of $\{0.94,1.05\}$ for the years 1960-79, compared with a confidence interval of $\{0.50$, $0.86\}$ for the years 1982-99. ${ }^{7}$ Similar conclusions have been reached by Evans and Wachtel (1993), who estimated a Markov regime-switching model of inflation, and by Cogley and Sargent (2001), who analyzed a vector autoregression with time-varying parameters. Thus, a high degree of inflation persistence does not seem to be an inherent characteristic of the U.S. economy. As we will see below, our approach is consistent with this evidence, because our model exhibits moderate persistence when monetary policy is transparent and credible, and much higher persistence when agents must use signal extraction to make inferences about the central bank's inflation target.

\subsection{A Brief Chronology of the Volcker Disinflation}

In October 1979, newly appointed Federal Reserve Chairman Paul Volcker announced a major shift in policy aimed at reducing the inflation rate. Volcker desired this policy change to be interpreted as a decisive break from past policies that had permitted inflation to rise to double-digit levels. As shown in Figure 2, the federal funds rate increased about 6 percentage points between October 1979 and April 1980, an unprecedented rise over such a short period. The contractionary effect of high real interest rates was reinforced by the implemention of extensive credit controls in March 1980. In response, GDP contracted at an annual rate of nearly 9 percent in 1980:2, the steepest one-quarter decline in the postwar period. Alarmed by the apparent free fall in output, the Federal Reserve quickly lowered interest rates: by mid-1980, short-term nominal and real interest rates fell slightly below their values prior to the October 1979 tightening.

\footnotetext{
${ }^{6}$ See Christiano and Gust (2000), Clarida, Gali, and Gertler (2000), and Orphanides (2000) for alternative views of why inflation rose during the late 1960s and 1970s.

${ }^{7}$ Even stronger evidence for this result is obtained when one allows for a post-1991 shift in the mean of the inflation process; for example, we found in this case that the largest autoregressive root of inflation is only 0.55 over the $1983-2000$ period.
} 
In late 1980, the Federal Reserve embarked on a new round of monetary tightening. The federal funds rate rose to 20 percent by early 1981, implying an ex post real interest rate of about 10 percent. Real interest rates were maintained near this extraordinarily high level until mid-1982. Volcker's aggressive anti-inflation policy succeeded in reducing the inflation rate from a 10 percent peak in late 1980 to around 4 percent by mid-1983, albeit at the cost of the most severe contraction in post-war U.S. history. Figure 3 shows the evolution of the output gap as measured by the OECD. Based on this measure of the output gap, the Volcker disinflation was associated with a sacrifice ratio of 1.7 percent. $^{8}$

\subsection{Inflation Forecast Errors and Credibility}

Figure 4 shows the four-quarter average inflation rate of the GDP price deflator and its expected value four quarters ahead (as measured by the median projection of the Survey of Professional Forecasters). The behavior of actual inflation and expected inflation seem consistent with the hypothesis that the Federal Reserve faced severe credibility problems in its efforts to reduce inflation. Despite the transient policy tightening that began in October 1979, both actual and expected inflation continued to rise over the next nine months. After renewed Federal Reserve tightening in late 1980, survey-based measures of expected inflation finally began to fall, suggesting somewhat greater confidence in the Fed's commitment to this policy stance. Nevertheless, realized inflation fell much more rapidly than was predicted, implying large and persistent inflation forecast errors (also shown in Figure 4). ${ }^{9}$ From 1981 to 1985, these forecast errors averaged over 1.5 percentage points. Figure 5 shows two measures of long-term expected inflation (the Barclay survey of inflation expectations 5-10 years ahead, and the Philadelphia Federal Reserve survey of the expected 10year average inflation rate). Both of these surveys indicate that long-term inflation expectations adjusted even more slowly. ${ }^{10}$

In light of these data, it appears that individuals did revise their inflation expectations in response to shifts in monetary policy, rather than simply adapting to current and lagged inflation rates. In particular, expected inflation began to decline in late 1980, whereas actual inflation did not begin to decline until early 1981. In fact, ex-

\footnotetext{
${ }^{8}$ The sacrifice ratio is estimated by dividing the cumulative undiscounted sum of the annualized output gap between 1980:H2 and 1984:H2 by the change in the inflation rate of the GDP deflator over the same period. For this calculation, we use the output gap series taken from the OECD Economic Outlook. Our estimate is close to the value of 1.8 obtained by Ball (1994b). Nevertheless, it should be recognized that estimated sacrifice ratios are somewhat sensitive to the specific measure of the output gap. For example, Sachs (1985), Blinder (1987), and Mankiw (1991) obtained somewhat higher estimates of the sacrifice ratio for the Volcker disinflation.

${ }^{9}$ The inflation forecast error in any quarter $t$ is measured as the difference between expected inflation in period $t$ and the realized inflation rate over the forecast period. Thus, the inflation forecast error shown in 1980:4 reflects the error in predicting the year-over-year inflation rate in 1981:4.

${ }^{10}$ Goodfriend (1993) draws attention to the slow convergence of long-term nominal interest rates. He interprets the temporary spike in nominal interest rates in 1983 as reflecting a continued lack of faith on the part of market participants in the Federal Reserve's willingness to maintain a tight hold on inflation.
} 
pected inflation remained below the current inflation rate throughout the subsequent year.

Furthermore, we interpret the persistent positive forecast errors reflecting substantial doubts about whether the Federal Reserve would continue to pursue a disinflationary policy. As Goodfriend (1993) has emphasized, such doubts were reasonably well-founded, given that the Federal Reserve had shown a high degree of tolerance for rising inflation in the 1970s and had aborted the monetary tightening that began in October 1979. A second capitulation became increasingly plausible as the severity of the 1982 recession became more apparent and generated mounting Congressional pressure. The forecasting problem was compounded by the fact that the Federal Reserve did not announce a target path or band for the inflation rate; indeed, as the disinflation progressed, it became increasing difficult to assess how far Volcker intended to push down the inflation rate. Thus, persistent forecast errors seem consistent with rational expectations subject to limited information, and do not necessarily reflect non-rational expectations.

\subsection{Evidence from Other Countries}

Although our analysis is primarily devoted to matching the behavior of the U.S. economy during the Volcker disinflation, it is interesting to note that similar patterns appear to be characteristic of the roughly contemporaneous disinflation episodes in the United Kingdom and Canada. As seen in Figure 6, the United Kingdom's shift towards an aggressive inflation-reduction strategy in 1981 succeeded in reducing the inflation rate from a peak of 20 percent in mid-1980 to around 5 percent by mid1983. ${ }^{11}$ Similarly, as shown in Figure 7, Canada's adoption of tighter policies in 1981 contributed to a fall in its inflation rate from double digit levels to around 3-4 percent by late-1983. ${ }^{12}$ As in the Volcker disinflation, both the U.K. and Canadian disinflations were associated with large and highly persistent inflation forecast errors. Moreover, the estimated sacrifice ratio for each country (1.4 for the United Kingdom and 1.3 for Canada) appear very similar to the estimate of 1.7 for the Volcker disinflation.

\section{$3 \quad$ The Model}

As in Erceg (1997), we assume that labor and product markets each exhibit monopolistic competition, that wages and prices are determined by staggered four-quarter nominal contracts, and that the capital stock is endogenously determined subject to

\footnotetext{
${ }^{11}$ See Sargent (1986) for discussion of the initial stages of the Thatcher disinflation.

${ }^{12}$ The inflation rate for the United Kingdom is the four quarter-change in the GDP price deflator, while the inflation rate for Canada is the four quarter-change in the GNP price deflator. The data on expected inflation are semiannual, and taken from successive issues of the OECD Economic Outlook. The inflation forecast reported in the first half of each year is taken from the December survey of the previous year, and represents the inflation rate expected to prevail over the subsequent four quarters; the inflation forecast reported in the second half of each year is taken from the mid-year survey (typically published in June or July).
} 
quadratic adjustment costs. ${ }^{13}$ The central bank is assumed to react to the deviation of the output price inflation rate from its target value, and to the growth rate of real output. The key assumption in our analysis is that the central bank's long-run inflation target cannot be directly observed by private agents.

\subsection{Firms and Price Setting}

Final Goods Production As in Chari, Kehoe, and McGratten (2000), we assume that households use a single final output good $Y_{t}$ either for consumption or investment. A continuum of differentiated intermediate goods $Y_{t}(f)(f \in[0,1])$ is transformed into the final output good using a constant returns-to-scale technology of the Dixit-Stiglitz form:

$$
Y_{t}=\left[\int_{0}^{1} Y_{t}(f)^{\frac{1}{1+\theta_{p}}} d f\right]^{1+\theta_{p}}
$$

where $\theta_{p}>0$.

Firms that produce the final output good are perfectly competitive in both product and factor markets. Thus, final goods producers minimize the cost of producing a given quantity of the output index $Y_{t}$, taking as given the price $P_{t}(f)$ of each intermediate good $Y_{t}(f)$. Moreover, the final output good is sold at a price $P_{t}$ that equals the marginal cost of production:

$$
P_{t}=\left[\int_{0}^{1} P_{t}(f)^{\frac{-1}{\theta_{p}}} d f\right]^{-\theta_{p}}
$$

It is natural to interpret $P_{t}$ as the aggregate price index.

Intermediate Goods Production Each intermediate good $Y_{t}(f)$ is produced by a single monopolistically competitive firm. This firm faces a demand function that varies inversely with its output price $P_{t}(f)$ and directly with aggregate demand $Y_{t}$ :

$$
Y_{t}(f)=\left[\frac{P_{t}(f)}{P_{t}}\right]^{\frac{-\left(1+\theta_{p}\right)}{\theta_{p}}} Y_{t}
$$

Each intermediate goods producer utilizes capital services $K_{t}(f)$ and a labor index $L_{t}(f)$ (defined below) to produce its respective output good. The form of the production function is Cobb-Douglas, with the level of total factor productivity $X_{t}$ identical across firms:

$$
Y_{t}(f)=X_{t} K_{t}(f)^{\alpha} L_{t}(f)^{1-\alpha}
$$

Firms face perfectly competitive factor markets for hiring capital and the labor index. Thus, each firm chooses $K_{t}(f)$ and $L_{t}(f)$, taking as given both the rental price of capital $R_{K t}$ and the aggregate wage index $W_{t}$ (defined below). Firms can costlessly adjust either factor of production. Thus, the standard static first-order conditions

\footnotetext{
${ }^{13}$ Under these assumptions, a transitory money growth shock has persistent effects on output and the aggregate price level, but not on the inflation rate; cf. Chari, Kehoe, and McGratten (2000), Erceg (1997), and Edge (2000).
} 
for cost minimization imply that all firms have identical marginal cost per unit of output. By implication, aggregate marginal cost $M C_{t}$ can be expressed as a function of the wage index $W_{t}$, the aggregate labor index $L_{t}$, the aggregate capital stock $K_{t}$, and total factor productivity $X_{t}$, or equivalently, as the ratio of the wage index to the marginal product of labor $M P L_{t}$ :

$$
\begin{gathered}
M C_{t}=\frac{W_{t} L_{t}^{\alpha}}{(1-\alpha) K_{t}^{\alpha} X_{t}}=\frac{W_{t}}{M P L_{t}} \\
M P L_{t}=(1-\alpha) K_{t}^{\alpha} L_{t}^{-\alpha} X_{t}
\end{gathered}
$$

We assume that the prices of the intermediate goods are determined by staggered nominal contracts of fixed duration. For concreteness, we assume that each price contract lasts four quarters, and that one-fourth of the firms reset their prices in a given period. Thus, individual producers may be indexed so that every firm with index $f \in[0,0.25]$ resets its contract price $P_{t}(f)$ whenever the date $t$ is evenly divisible by 4 ; similarly, firms with index $f \in[0.25,0.5]$ set prices during periods in which $\bmod (t, 4)=1$, and so forth. For a firm which resets its price during period $t$, $P_{t+j}(f)=P_{t}(f)$ for $j=1,2,3$. The firm chooses the value of $P_{t}(f)$ which maximizes the firm's discounted profits over the life of the price contract, subject to its product demand curve (3):

$$
\widetilde{\mathbb{E}}_{t} \sum_{j=0}^{3} \psi_{t, t+j}\left(\left(1+\tau_{p}\right) P_{t}(f) Y_{t+j}(f)-M C_{t+j} Y_{t+j}(f)\right)
$$

The operator $\widetilde{\mathbb{E}}_{t}$ represents the conditional expectation based on all information available to private agents at period $t .{ }^{14}$ Note that the tilde above the expectations operator is meant to indicate that private agents do not have complete information about the central bank's policy rule. The firm's output is subsidized at a fixed rate $\tau_{p}$. The firm discounts profits received at date $t+j$ by the discount factor $\psi_{t, t+j} \cdot{ }^{15}$

The first-order condition for a price-setting firm is

$$
\widetilde{\mathbb{E}}_{t} \sum_{j=0}^{3} \psi_{t, t+j}\left(\frac{\left(1+\tau_{p}\right)}{\left(1+\theta_{p}\right)} P_{t}(f)-M C_{t+j}\right) Y_{t+j}(f)=0
$$

Roughly speaking, the firm sets its contract price so that its expected discounted nominal marginal revenue (inclusive of subsidies) is equal to its discounted nominal marginal cost. We assume that production is subsidized to eliminate the monopolistic distortion associated with a positive markup; that is, $\tau_{p}=\theta_{p}$.

\footnotetext{
${ }^{14}$ For simplicity, the variables in equation (7) are not explicitly indexed by the state of nature.

${ }^{15}$ The state-contingent discount factor $\psi_{t, t+j}$ indicates the price in period $t$ of a claim that pays one dollar in a given state of nature in period $t+j$, divided by the probability that state will occur.
} 


\subsection{Households and Wage Setting}

We assume a continuum of monopolistically competitive households (indexed on the unit interval), each of which supplies a differentiated labor service to the production sector; that is, goods-producing firms regard each household's labor services $N_{t}(h), h \in[0,1]$, as an imperfect substitute for the labor services of other households. It is convenient to assume that a representative labor aggregator (or "employment agency") combines households' labor hours in the same proportions as firms would choose. Thus, the aggregator's demand for each household's labor is equal to the sum of firms' demands. The labor index $L_{t}$ has the Dixit-Stiglitz form:

$$
L_{t}=\left[\int_{0}^{1} N_{t}(h)^{\frac{1}{1+\theta_{w}}} d h\right]^{1+\theta_{w}}
$$

where $\theta_{w}>0$. The aggregator minimizes the cost of producing a given amount of the aggregate labor index, taking each household's wage rate $W_{t}(h)$ as given, and then sells units of the labor index to the production sector at their unit $\operatorname{cost} W_{t}$ :

$$
W_{t}=\left[\int_{0}^{1} W_{t}(h)^{\frac{-1}{\theta_{w}}} d h\right]^{-\theta_{w}}
$$

It is natural to interpret $W_{t}$ as the aggregate wage index. The aggregator's demand for the labor hours of household $h$ - or equivalently, the total demand for this household's labor by all goods-producing firms - is given by

$$
N_{t}(h)=\left[\frac{W_{t}(h)}{W_{t}}\right]^{-\frac{1+\theta_{w}}{\theta_{w}}} L_{t}
$$

The utility functional of household $h$ is

$$
\widetilde{\mathbb{E}}_{t} \sum_{j=0}^{\infty} \beta^{j}\left\{\frac{1}{1-\sigma}\left(C_{t}(h)\right)^{1-\sigma}+\frac{1}{1-\chi}\left(1-N_{t}(h)\right)^{1-\chi}+\frac{\mu_{0}}{1-\mu}\left(\frac{M_{t+j}(h)}{P_{t+j}}\right)^{1-\mu}\right\}
$$

where the discount factor $\beta$ satisfies $0<\beta<1$. The period utility function depends on consumption $C_{t}(h)$, leisure $1-N_{t}(h)$, and real money balances. $\frac{M_{t}(h)}{P_{t}}$.

Household $h$ 's budget constraint in period $t$ states that its expenditure on goods and net purchases of financial assets must equal its disposable income:

$$
\begin{gathered}
P_{t} C_{t}(h)+P_{t} I_{t}(h) \\
M_{t+1}(h)-M_{t}(h)+\int \delta_{t+1, t} B_{t+1}(h)-B_{t}(h) \\
=T_{t}(h)+\left(1+\tau_{w}\right) W_{t}(h) N_{t}(h)+\Gamma_{t}(h)+ \\
R_{K t} K_{t}(h)-0.5 \phi_{K} P_{t} K_{t}(h)\left(\frac{I_{t}(h)}{K_{t}(h)}-\delta\right)^{2}
\end{gathered}
$$

The household purchases the final output good (at a price of $P_{t}$ ), which it chooses either to consume $C_{t}(h)$ or invest $I_{t}(h)$ in physical capital. Investment in physical 
capital augments the household's (end-of-period) capital stock $K_{t+1}(h)$ according to a linear transition law of the form:

$$
K_{t+1}(h)=(1-\delta) K_{t}(h)+I_{t}
$$

Financial asset accumulation consists of increases in money holdings and the net acquisition of state-contingent claims. Each element of $\delta_{t+1, t}$ represents the current price of an asset that will pay one unit of currency if a particular state of nature occurs in the subsequent period, while the corresponding element of $B_{t+1}(h)$ represents the quantity of such claims purchased by the household. $B_{t}(h)$ indicates the value of the household's claims given the current realization of the state of nature.

Household $h$ 's disposable income consists of a lump-sum government transfer $T_{t}(h)$, labor income of $\left(1+\tau_{w}\right) W_{t}(h) N_{t}(h)$, and capital income net of adjustment costs. Pre-tax labor income $W_{t}(h) N_{t}(h)$ is subsidized at a fixed rate $\tau_{w} \cdot{ }^{16}$ Each household receives an aliquot share of the profits of all firms $\Gamma_{t}(h)$, and gross rental income of $R_{K t} K_{t}(h)$ from renting its capital stock to firms. Households incur a cost of adjusting their net stock of physical capital. Adjustment costs are assumed to depend on the square of the deviation of the investment-to-capital ratio from its steady state level level of $\delta$ (or equivalently, on the square of the net change in the capital stock).

In every period $t$, each household maximizes the utility functional (12) with respect to its consumption, investment, (end-of-period) capital stock, money balances, and holdings of contingent claims, subject to its labor demand function (11) its budget constraint (13), and the transition equation for capital (14). The first-order conditions for consumption and for holdings of state-contingent claims imply the familiar consumption Euler equation linking the marginal cost of foregoing a unit of consumption in the current period $\left(\Lambda_{t}=C_{t}^{-\sigma}\right)$ to the expected discounted marginal benefit:

$$
\widetilde{\mathbb{E}}_{t} \Lambda_{t}=\widetilde{\mathbb{E}}_{t}\left[\beta\left(1+R_{t}\right) \Lambda_{t+1}\right]=\widetilde{\mathbb{E}}_{t}\left[\beta\left(1+I_{t}\right) \frac{P_{t}}{P_{t+1}} \Lambda_{t+1}\right]
$$

where the risk-free real interest rate $R_{t}$ is the rate of return on an asset that pays one unit of the output index under every state of nature at time $t+1$, and the nominal interest rate $I_{t}$ is the rate of return on an asset that pays one unit of currency under every state of nature at time $t+1$. Our assumption of complete contingent claims markets for consumption implies that consumption is identical across households in every period $\left(C_{t}(h)=C_{t}\right)$, and hence that all households have the same marginal value of a unit of the output index. This enables us to omit household-specific subscripts.

The household's Euler condition for investment implies a linear contemporaneous relation between Tobin's q and the investment to capital ratio of the form:

$$
q_{t}=1-\phi_{K} \delta+\phi_{K} \frac{I_{t}}{K_{t}}
$$

\footnotetext{
${ }^{16}$ The government's budget is balanced every period, so that total lump-sum transfers are equal to seignorage revenue less output and labor subsidies.
} 
Here $\mathrm{q}_{t}$ is the current value to the household of a unit of capital that becomes productive in the following period (measured in units of the final output good). Substituting this relation into the Euler equation for capital yields:

$$
\begin{aligned}
& R_{t}+\delta=\widetilde{\mathbb{E}}_{t} \frac{R_{K t+1}}{P_{t+1}}-\left(1+R_{t}\right) \phi_{K} \widetilde{\mathbb{E}}_{t}\left(\frac{K_{t+1}-K_{t}}{K_{t}}\right)+ \\
& \phi_{K} \widetilde{\mathbb{E}}_{t}\left(\frac{K_{t+2}-K_{t+1}}{K_{t+1}}\right)+\frac{1}{2} \phi_{K} \widetilde{\mathbb{E}}_{t}\left(\frac{K_{t+2}-K_{t+1}}{K_{t+1}}\right)^{2}
\end{aligned}
$$

In the absence of adjustment costs, the household would simply accumulate capital until the expected real rental return equaled the marginal cost, including foregone interest and depreciation. Adjustment costs drive a wedge between the expected rental return and marginal cost that increases in the level of net investment.

Households set nominal wages in staggered contracts that are analogous to the price contracts described above. In particular, we assume that wage contracts last four periods, and that the households are divided into four cohorts of equal size. In each period, the households in one cohort renegotiate their wage contracts, while the nominal wages of all other households remain unchanged. Thus, for a household which resets its contract wage $W_{t}(h)$ during period $t, W_{t+j}(h)=W_{t}(h)$ for $j=1,2,3$. The household chooses the value of $W_{t}(h)$ to maximize its utility functional (12), yielding the following first-order condition:

$$
\widetilde{\mathbb{E}}_{t} \sum_{j=0}^{3} \beta^{j}\left(\frac{\left(1+\tau_{w}\right)}{\left(1+\theta_{w}\right)} \frac{\Lambda_{t+j}}{P_{t+j}} W_{t}(h)-\left(1-N_{t}(h)\right)^{-\chi}\right) N_{t+j}(h)=0
$$

The discount factor $\frac{\beta^{j} \Lambda_{t+j}}{P_{t+j}}$ represents the current marginal utility of an additional dollar received $j$ periods in the future. Roughly speaking, equation (18) says that the household chooses its contract wage to equate the present discounted value of working an additional unit of time to the discounted marginal cost. We assume that employment is subsidized to eliminate the monopolistic distortion associated with a positive markup; that is, $\tau_{w}=\theta_{w}$. If contracts last only one period, this condition reduces to the familiar equality between the real wage and marginal rate of substitution of consumption for leisure.

\subsection{Monetary Policy}

The appropriate characterization of Federal Reserve policy during the Volker disinflation period remains a subject of contention. However, Goodfriend (1991, 1993) argues persuasively that it is reasonable to consider the federal funds rate as the best measure of the stance of U.S. monetary policy even during this period. ${ }^{17}$ Based on this

\footnotetext{
${ }^{17}$ From 1979:4 to 1982:3, the Federal Reserve's stated operational target involved the stock of nonborrowed reserves. Nevertheless, as Cook (1989) and Goodfriend (1991, 1993) have emphasized, the federal funds rate remained the main instrument of monetary policy, because the Federal Reserve made numerous discretionary adjustments to influence the amount of credit extended through the
} 
perspective, we assume that the central bank adjusts the short-term nominal interest rate so that the ex post real interest rate rises when inflation exceeds its target value of $\pi_{t}^{*}$, or output growth rises above its trend rate. In addition, as in much of the subsequent literature, we allow for some degree of nominal interest rate smoothing or policy inertia. In particular, monetary policy is described by the following interest rate reaction function:

$$
i_{t}=\gamma_{i} i_{t-1}+\left(1-\gamma_{i}\left[\bar{r}+\pi_{t}^{(4)}+\gamma_{\pi}\left(\pi_{t}^{(4)}-\pi_{t}^{*}\right)+\gamma_{y}\left(\ln \left(y_{t} / y_{t-4}\right)-\bar{g}_{y}\right)\right]\right.
$$

where the four-quarter average inflation rate $\pi_{t}^{(4)}=\frac{1}{4} \sum_{j=0}^{3} \pi_{t-j}, \bar{r}$ is the steady-state real interest rate, and $\bar{g}_{y}$ is the steady-state output growth rate. Note that this interest rate reaction function involves the output growth rate and not the level of the output gap; as discussed below, this specification is consistent with our empirical analysis of interest rate determination from 1980 through 1985.

We assume that the inflation target $\pi_{t}^{*}$ varies over time due to a combination of transitory and highly persistent shocks. Households and firms are assumed to know the form of the central bank's reaction function, including the parameters determining the sensitivity of the nominal interest rate to the inflation rate, the output growth rate, and the lagged interest rate (that is, the parameters $\gamma_{\pi}, \gamma_{y}$, and $\gamma_{i}$, respectively). While agents can infer the current value of the inflation target from knowledge of the central bank's reaction function, they cannot directly observe the underlying components of $\pi_{t}^{*}$. Thus, agents must solve a signal extraction problem in order to forecast the future path of the inflation target, which in turn influences the outcome of their current decisions (e.g., in setting new wage and price contracts). ${ }^{18}$

In our baseline specification, we formulate the signal extraction problem by assuming that the central bank's inflation target is the sum of a constant steady state rate of inflation $\bar{\pi}$ and two zero-mean stochastic components. Equivalently:

$$
\pi_{t}^{*}-\bar{\pi}=\left(\pi_{p t}-\bar{\pi}\right)+\pi_{q t}=H \xi_{t}
$$

where $H=\left[\begin{array}{ll}1 & 1\end{array}\right]$ and $\xi_{t}=\left[\begin{array}{lll}\left(\pi_{p t}-\bar{\pi}\right) & \pi_{q t}\end{array}\right]$. The time-varying components are determined by the following first-order vector autoregression:

$$
\begin{gathered}
{\left[\begin{array}{c}
\pi_{p t+1}-\bar{\pi} \\
\pi_{q t+1}
\end{array}\right]=\left[\begin{array}{cc}
\rho_{p} & 0 \\
0 & \rho_{q}
\end{array}\right]\left[\begin{array}{c}
\pi_{p t}-\bar{\pi} \\
\pi_{q t}
\end{array}\right]+\left[\begin{array}{l}
\varepsilon_{p t+1} \\
\varepsilon_{q t+1}
\end{array}\right]} \\
\text { or } \\
\xi_{t+1}=F \xi_{t}+\varepsilon_{t+1}
\end{gathered}
$$

discount window. On this basis, prominent monetarists such as Friedman (1983) and Brunner (1983) criticized the Federal Reserve's failure to adopt a strict monetarist approach.

\footnotetext{
${ }^{18}$ Our formulation of the information problem is formally similar to that in Brunner, Cukierman, and Meltzer (1980), and in Gertler (1982). The latter showed how imperfect observability of the underlying components of the money supply process could induce "inertial" behavior in the level of the nominal wage.
} 
For simplicity, we assume that the highly persistent component $\left(\pi_{p t}-\bar{\pi}\right)$ has an autoregressive root $\rho_{p}$ arbitrarily close to unity, while the transitory component $\pi_{q t}$ has a much smaller autoregressive root $\rho_{q}$. Thus, while we assume the central bank's inflation target eventually returns to its steady state value of $\bar{\pi}$, the shock $\varepsilon_{p t}$ drives the inflation target away from steady state for a very prolonged period. On the other hand, the shock $\varepsilon_{q t}$ has only a very transient effect on the target.

Finally, we assume that the inflation target innovations $\varepsilon_{p t}$ and $\varepsilon_{q t}$ are mutually uncorrelated with variances $v_{1}$ and $v_{2}$, respectively, and are not correlated with any other shocks to the model economy. Thus, the Kalman filter can be used to obtain an optimal solution to the signal-extraction problem. In particular, optimal estimates of the unobserved components can be obtained recursively as follows:

$$
\widetilde{\mathbb{E}}_{t} \xi_{t}=F \widetilde{\mathbb{E}}_{t-1} \xi_{t-1}+L_{\text {gain }}\left(\pi_{t}^{*}-H F \widetilde{\mathbb{E}}_{t-1} \xi_{t-1}\right)
$$

where the Kalman gain matrix $K_{\text {gain }}=F L_{\text {gain }}$. The term $\pi_{t}^{*}-H F \widetilde{\mathbb{E}}_{t-1} \xi_{t-1}$ is the one-step-ahead forecast error in predicting $\pi_{t}^{*}$ based on its previous values, while the matrix $L_{\text {gain }}$ determines how agents respond to a given forecast error by updating their estimates of the underlying components of the inflation target. Finally, given

the current estimate $\widetilde{\mathbb{E}}_{t} \xi_{t}$ of these components, the optimal forecast of the inflation target $J$ periods ahead is given by:

$$
\widetilde{\mathbb{E}}_{t} \pi_{t+J}^{*}=H F^{J} \widetilde{\mathbb{E}}_{t} \xi_{t}
$$

\section{Solution and Calibration}

To analyze the behavior of this model, we log-linearize the model's equations around the non-stochastic steady state associated with a constant inflation rate of $\bar{\pi}$ (that is, the central bank's steady-state inflation target). Nominal variables, such as the contract price and wage, are rendered stationary by suitable transformations. The log-linearized model consists of four key behavioral equations (the Euler equations for consumption (15), the capital stock (17), price-setting (8), and wage-setting (18)), three equations determining actual monetary policy ((19), (20), and (21)), and two equations determining private sector expectations of the inflation target $((22)$ and $(23))$.

\subsection{Parameters of Private Sector Behavioral Equations}

The model is calibrated at a quarterly frequency. Thus, we assume that the discount factor $\beta=.993$, consistent with a steady-state annualized real interest rate $\bar{r}$ of about 3 percent. The utility function is assumed to be logarithmic in consumption, leisure, and real balances, implying that $\sigma=\chi=\mu=1$. The Cobb-Douglas capital share parameter $\alpha=0.3$, and the depreciation rate of capital $\delta=.025$ (consistent with an annual depreciation rate of 10 percent). The price and wage markup parameters are 
both set equal to $1 / 3$, so $\theta_{P}=\theta_{W}=1 / 3$. We set the steady state inflation rate $\bar{\pi}$ equal to an annual rate of four percent.

We draw on the empirical q-theory literature to calibrate a baseline value of the capital adjustment cost parameter $\phi_{K}$. Recent literature estimating a linear regression of $\frac{I_{t}}{K_{t}}$ on $q_{t}$ - consistent with equation (16) in our model - includes Eberly (1997) and Cummins, Haskett, and Oliner (1997). Eberly's estimates using U.S. data of the regression coefficient on $q_{t}$ range from 0.09 (ordinary least squares) to 0.17 (instrumental variables), implying values of $\phi_{K}$ of 11.1 and 5.6, respectively. Cummins, Haskett, and Oliner estimate regression coefficients on $q_{t}$ ranging from .08 (ordinary least squares) to .11 (instrumental variables), implying values of $\phi_{K}$ of 12.5 and 9 , respectively. We set our baseline value of $\phi_{K}=6$, near the lower bound of the range of estimates of adjustment costs suggested by this literature. Our choice is in part motivated by the fact that difficulty in measuring Tobins's q is likely to lead to upward bias in estimates of adjustment costs using the standard q-theory approach (as suggested by Shapiro (1986)). ${ }^{19}$ However, we also conduct sensitivity analysis in the results presented below.

\subsection{Monetary Policy Rule Parameters}

The parameters of the interest rate reaction function (19) are estimated over the 1980:4-1985:4 period by two-stage least squares. In estimating this equation, we assume that the Federal Reserve maintained a constant value of $\pi_{p t}$ throughout this period; that is, we identify the error term in the estimated monetary policy reaction function as arising solely from variation in $\pi_{q t}$ (the transitory component of the inflation target). We use two-stage least squares (with lagged values of inflation, output growth, and the nominal interest rate as instruments) to correct for possible correlation between the error term and the contemporaneous four-quarter inflation rate and output growth rate; in practice, however, OLS and 2SLS give reasonably similar results over the estimation period. We obtain parameter estimates of $\gamma_{\pi}=0.64, \gamma_{y}=$ 0.25 , and $\gamma_{i}=0.21$. We also experimented with adding the level of the output gap to the interest rate reaction function, but found that this variable was not statistically significant. ${ }^{20}$

Figure 8 compares the actual federal funds rate with the fitted values implied by these coefficient estimates. Evidently, this simple specification performs remarkably well in describing monetary policy during the sample period: the estimated residuals are relatively small compared with the movements in the federal funds rate itself, and these residuals exhibit negligible serial correlation. ${ }^{21}$

\footnotetext{
${ }^{19}$ Our baseline choice of $\phi_{K}=6$ implies that the half-life of the response of the aggregate capital stock to a one percent permanent rise in the real interest rate (under perfect foresight) is about 14 quarters, assuming that aggregate labor hours are held fixed.

${ }^{20}$ Interestingly, Orphanides and Wieland (1998) estimated the interest rate reaction function over a longer period (1980:1 to 1996:4), and found that the level of output and lag of the level of output entered with a nearly equal but opposite sign.

${ }^{21}$ The monetary policy reaction function appears quite stable even over short very subsamples of Volker's tenure, at least for estimation periods beginning at or around the period of renewed
} 


\subsection{Evolution of the Inflation Target}

We set the autoregressive parameter $\rho_{p}$ on the highly persistent component of the inflation target $\left(\pi_{p t}-\bar{\pi}\right)$ equal to 0.999 , while the autoregressive parameter $\rho_{q}$ is set equal to zero in our baseline. The latter choice is consistent with our empirical finding that the historical innovations in the monetary policy reaction function over the 1980:4-1985:4 period are close to white noise.

Under these assumptions, the expected future inflation target $\widetilde{\mathbb{E}}_{t} \pi_{t+j}^{*}(j>0)$ depends only on a constant $(\bar{\pi})$ and the expectation of the highly persistent component of the target $\widetilde{\mathbb{E}}_{t}\left(\pi_{p t+j}\right)$. In this special case of equation (22) with $\rho_{q}=0$, the persistent component of the target evolves according to:

$$
\widetilde{\mathbb{E}}_{t}\left(\pi_{p t}-\bar{\pi}\right)=\rho_{p} \widetilde{\mathbb{E}}_{t-1}\left(\pi_{p t-1}-\bar{\pi}\right)+\left[\frac{k_{g}}{\rho_{p}}\right]\left(\pi_{t}^{*}-\widetilde{\mathbb{E}}_{t-1} \pi_{t}^{*}\right)
$$

Thus, agents update their assessment of the persistent component of the inflation target by the product of the forecast error innovation and a constant coefficient. This coefficient, which is proportional to the scalar Kalman gain parameter $k_{g}$, is an increasing function of the signal-to-noise ratio $\frac{v_{1}}{v_{2}}$ (the ratio of the variances of the persistent and transitory components of the inflation target).

In estimating the signal-to-noise ratio, we utilize the same assumptions described above, namely, that the Federal Reserve maintained a constant value of $\pi_{p t}$ after 1980:4, so that the path of the transient component $\pi_{q t}$ can be computed from the residuals in the estimated monetary policy rule. We proceed by minimizing the sum of squared deviations between the observed data on four quarter-ahead expected inflation over the period 1980:4 to 1985:4 (taken from Survey of Professional Forecasters) and the corresponding inflation expectations implied by our model. Our point estimate of $\frac{v_{1}}{v_{2}}$ implies a value of the Kalman gain of 0.13 . Thus, using equation (24), we find that nearly half of a given change in $\pi_{p t}$ is incorporated into agents'expectations within a year.

\section{Results}

In this section, we analyze the behavior of the calibrated model in response to a shock to the highly persistent component $\pi_{p t}$ of the inflation target. In particular, we assume that $\pi_{p t}$ falls from an initial value of 10 percent to its steady-state level of 4 percent (annual rates); this shock is roughly equal to the decline in the GDP price inflation rate during the Volcker disinflation. The shock is assumed to occur in 1980:4.

\subsection{The Baseline Calibrated Model}

Full Information about the Inflation Target. The dashed lines in Figure 9 show the impulse response functions (IRFs) of the model when private agents have full infor-

tightening in late 1980. 
mation about the central bank's inflation target; that is, agents correctly interpret the reduction in the inflation target as a persistent shock and have perfect foresight about the subsequent path of $\pi_{t}^{*}$. Inflation falls from 10 percent to 4 percent within a year, and exhibits very little persistence beyond the length of the four-quarter nominal contracts. The short-term nominal interest rate falls slightly in the initial period (1980:4) and is close to steady state within a couple of quarters. Real output initially declines markedly, but rebounds above baseline shortly thereafter. The initial output contraction occurs because the estimated monetary policy rule implies a sharp jump in the ex ante real interest rate. However, given that inflation expectations are anchored by the new lower target, progress in reducing inflation allows nominal and real interest rates to fall quickly and thereby causes output to rebound.

These results are qualitatively similar to those obtained by Ball (1994) and Fuhrer and Moore (1995). Although those authors utilized models with staggered price contracts and flexible wages, it is clear that the inclusion of staggered wage contracts in our model does not generate much additional inflation persistence. Furthermore, while the output costs of disinflation depend on the sensitivity of real marginal cost to output and on the form of the monetary policy reaction function, these factors have minimal effect on the duration of a disinflation episode when agents have full information about the shift in the inflation target.

Imperfect Observability of the Inflation Target. The solid lines in Figure 9 show the IRFs of the baseline version of the calibrated model; that is, the signal-to-noise ratio is set to its estimated value (implying a Kalman gain of 0.13), and hence private agents gradually learn about the persistent shock to the inflation target. It is evident from Figure 9 that the signal extraction problem plays a critical role in accounting for the broad features of the Volcker disinflation episode, namely, sluggish inflation adjustment, a persistently negative output gap, and an initial rise in the nominal interest rate. Inflation exhibits much greater persistence in this case: only about half the decline in inflation occurs within a year, and inflation is still only $3 / 4$ of the way toward steady state after two years. Our model's predicted path for inflation in the six quarters following the shock is in fact very close to what was observed in the Volcker disinflation. The slow inflation decline in our model reflects that current inflation is partly anchored by expectations about the future inflation target.

In this case, the output gap exhibits a substantial and persistent decline, which contrasts strongly with the results for the case in which private agents have complete information about the inflation target. In particular, since current inflation decreases slowly, the policy rule requires high ex ante real interest rates over a sustained period. Output is about four percent below potential during the first year after the disinflation shock, and only recovers gradually as the central bank reduces interest rates in response to falling inflation. Thus, our calibrated model yields a sacrifice ratio of about 1.6 during the five years after the disinflation shock, a result which is remarkably close to the empirical estimate of 1.7 , and broadly in line with the estimates for Canada and the United Kingdom discussed in Section 2.4.

Furthermore, the nominal interest rate rises initially by about 300 basis points, an implication that contrasts sharply with the results obtained under full information (for which the nominal interest rate starts falling immediately at the start of the 
disinflation). This difference in nominal interest rate behavior results from the greater sluggishness of inflation and because output exhibits a smaller initial contraction than under complete information.

Finally, while the signal-to-noise parameter is calibrated to fit the four quarterahead expected inflation rate, it is interesting to note that our simple specification generates comovement of actual and expected inflation that is quite similar to that observed in the Volcker disinflation and in the roughly contemporaneous disinflation in the United Kingdom (cf. Figures 4 and 6, respectively). Expected inflation falls sharply below current inflation at the announcement of the disinflation, but then declines somewhat more slowly thereafter. As emphasized in Section 2, this pattern clearly departs from what one would expect if private agents' expectations evolved in a simple adaptive fashion. In the medium term, inflation expectations move quite closely with actual inflation, demonstrating that persistent positive forecast errors are not inconsistent with rational expectations subject to limited information about the central bank's objectives.

\subsection{Sensitivity Analysis}

We now consider sensitivity analysis to assess the features of our model that help it to account for an empirically plausible sacrifice ratio. One crucial feature is endogenous capital accumulation. Figure 10a shows the responses of output, consumption, and investment to the disinflation shock in the baseline calibrated model. Although the baseline investment share of output is only slightly over 20 percent, a sharp drop in investment accounts for nearly half of the output decline at the recession trough in the first half of 1981 .

As shown in Figure 10b, the magnitude of the output decline in our model (and hence the sacrifice ratio) is somewhat sensitive to the calibration of the adjustment cost parameter $\phi_{K}$. The solid line depicts the response under our baseline calibration $\left(\phi_{K}=6\right)$. The dotted line depicts the case of extremely high adjustment costs $\left(\phi_{K}=100\right)$; in this case, investment does not respond at all, and the output response is sufficiently damped that the sacrifice ratio is only 0.7 (less than half its baseline value). The dashed line depicts a reasonable upper bound on the magnitude of adjustment costs estimated in the q-theory literature (namely, $\phi_{K}=12$ ), implying a half-life of over 5 years for the adjustment of the capital stock to a permanent rise in the real interest rate. ${ }^{22}$ With these relatively high adjustment costs, the output response is somewhat lower than under the baseline calibration, yielding a sacrifice ratio of only 1.1. Finally, to take account of possible upward bias in the empirical q-theory literature, the dot-dashed line depicts relatively low adjustment $\operatorname{costs}\left(\phi_{K}=2\right)$; in this case, the sacrifice ratio rises to 2.2 .

Nominal wage rigidity also raises the magnitude of the output response to the disinflation shock. The dashed line in Figure 10c indicates the output response with four-quarter price contracts and flexible wages, while the solid line indicates the results

\footnotetext{
${ }^{22}$ Given the probable upward bias of adjustment cost estimates in the empirical q-theory literature, it seems very unlikely that the true adjustment cost parameter would be any larger than $\varphi=12$.
} 
for the baseline model (with four-quarter wage and price contracts). With flexible wages, the model yields a sacrifice ratio of only 1.0, compared with a sacrifice ratio of 1.6 for the baseline model. Intuitively, nominal wage inertia reduces the sensitivity of real marginal cost to the output gap. Because price inflation depends on current and expected future real marginal costs, price inflation falls less in response to a given output gap as wages become less flexible. Thus, in the context of a disinflation shock, nominal wage inertia implies that the real interest rate rises by a larger amount under the monetary policy rule (because price inflation remains further above target), and hence output declines more sharply relative to the case of completely flexible wages.

Finally, the output response is somewhat sensitive to the inflation coefficient $\left(\gamma_{\pi}\right)$ in the interest rate reaction function. To illustrate this sensitivity, we consider variants in which this coefficient is two standard deviations above or below its estimated value. The solid line indicates the response for the baseline calibrated model $\left(\gamma_{\pi}=0.64\right)$, while the dashed line indicates a more aggressive response to the inflation rate $\left(\gamma_{\pi}=1.05\right)$, and the dot-dashed line indicates a less aggressive policy response $\left(\gamma_{\pi}=0.23\right)$. The output gap trough occurs at roughly the same date in all three cases, but the magnitude of the output contraction obviously increases with the aggressiveness of the policy response to deviations of inflation from target.

\subsection{Inflation Forecast Errors}

Our model's ability to generate inflation persistence clearly depends on highly autocorrelated expectational errors in forecasting the central bank's inflation target, and correspondingly in forecasting inflation itself. For our interpretation to be empirically plausible, it is essential that the magnitude of the forecast errors implied by our model should not markedly exceed the observed pattern during the Volcker disinflation. In fact, Figure 11 shows that the inflation forecast errors implied by our model tend to be considerably smaller than those implied by the data. The dotted line indicates the forecast errors implied by our model in response to a fall in the persistent component of the inflation target alone, while the dash-dotted line indicates the pattern of forecast errors if the historical monetary policy innovations are also included. In either case, the forecast errors implied by the model are bounded by the historical forecast errors throughout the Volcker disinflation (except in 1980:4, the initial period of the shock). Thus, our model does not require implausibly large forecast errors in order to explain a high degree of inflation persistence.

Interestingly, the historical data exhibit a considerably higher degree of persistence in inflation forecast errors compared with those implied by our model. In particular, while our simple specification of the inflation target process implies a geometric pattern of convergence in the inflation forecast errors, the observed forecast errors show little tendency to decline, even several years after the initiation of the disinflation. For example, short-run inflation expectations in early 1984 remained in the range of 5 percent, nearly 2 percentage points higher than the realized inflation rate. Moreover, survey data on long-term expected inflation show a considerably more sluggish decline than is implied by our calibrated model. 


\subsection{Output Persistence}

We have shown that our model can account for a highly persistent downturn in the level of output in response to a disinflation, implying an empirically plausible sacrifice ratio. However, even under imperfect observability, a disinflation has a highly frontloaded effect on the level of output, with the output trough occuring only two to three quarters after the shock. The path of output implied by our model in response to a disinflation shock is shown by the dotted line in Figure 12 (with the dash-dot line showing the model output path when the historical monetary policy innovation is also included). It is clear that the model implies a much more rapid downturn than actually occurred in the Volcker disinflation; in the historical episode, output reached a trough only in mid-1982, more than a year-and-a-half later than the monetary policy tightening. The rapid output response reflects that the expenditure components of output in our model show very little persistence in growth rate terms. As we have seen in Figure 10b, increasing the cost of adjusting the capital stock does not delay the timing of the investment trough, but simply dampens the response of investment expenditures.

Accounting for persistent effects of shocks on the growth rate of output is a challenge to a broad class of models with optimizing agents, and in our model, greater output persistence would certainly enhance its ability to account for the behavior of other endogenous variables. For example, with a sharp initial downturn in output, the nominal interest rate in our model does not peak as sharply as in the data. Although not shown here, we have found that output persistence is not substantially affected by incorporating habit persistence in consumption into the baseline model. In future research, it will be useful to consider these issues in models with timing lags in investment decisions (cf. Edge (2000b)), which may be somewhat more successful in accounting for the delayed output downturns that seem to have characterized historical disinflation episodes.

\section{Comparison with Existing Literature}

As shown above, our formulation of staggered four-quarter wage and price contracts is useful in accounting for empirically reasonable costs of disinflation. In contrasting our approach with the existing literature, however, it is useful to consider the following stylized representation of the aggregate supply relation:

$$
\pi_{t}=\beta \hat{\pi}_{t+1}+\lambda x_{t}
$$

where $\pi_{t}$ is the one-quarter annualized inflation rate, $x_{t}$ is the deviation of output from its flexible-price level, and $\hat{\pi}_{t+1}$ is the one-step-ahead inflation forecast; in this specification, the parameters satisfy $0<\beta \leq 1$ and $\lambda>0$.

Equation (25) is immediately recognizable as the workhorse New Keynesian Phillips Curve under the assumption that agents make rational inflation forecasts using all information at time $t$; that is, $\hat{\pi}_{t+1}=\mathbb{E}_{t} \pi_{t+1}$, where we use the operator $\mathbb{E}_{t}$ (without 
a tilde) to indicate that private agents have full information about monetary policy (including the central bank's inflation target). In particular, as shown by Yun (1996) and others, this equation can be derived from microeconomic foundations when prices are determined by Calvo-style contracts and wages are completely flexible. This formulation exhibits no intrinsic inflation persistence and implies that disinflations can be conducted without any output costs.

One approach to accounting for inflation persistence has been to incorporate lagged inflation terms into equation (25) while maintaining the assumption that agents make rational forecasts (cf. Clarida et al. 1999):

$$
\pi_{t}=\theta \pi_{t-1}+(1-\theta) \beta \widetilde{\mathbb{E}}_{t} \pi_{t+1}+\lambda x_{t}
$$

When $\theta=1 / 2$ and $\beta=1$, equation (26) can be viewed as representing overlapping two-period relative real wage contracts (cf. Buiter and Jewitt 1981). As shown by Fuhrer and Moore (1995), this approach can account for very high inflation persistence and substantial costs of disinflation. Nevertheless, rigorous microeconomic foundations for this specification have not been provided; furthermore, as pointed out by Roberts (1997), the relative real wage contract specification has unpalatable implications for the level of real wages.

An alternative approach has been to assume that some agents do not have rational expectations. For example, Roberts (1998) considers a specification in which a fraction $\theta$ of private agents make one-step-ahead inflation forecasts based on past inflation, while the remaining agents have rational expectations; evidently, this specification can be represented exactly as in equation (26), but with a different structural interpretation than that of Fuhrer and Moore (1995). ${ }^{23}$ Of course, this approach departs from the optimizing-agent framework, in which agents use information efficiently in making their forecasts. Furthermore, as noted above, survey data on inflation expectations clearly incorporate additional information beyond that contained in lagged inflation data.

In contrast, our approach assumes that private agents have rational expectations but must use signal extraction to make inferences about the central bank's inflation target; that is, we assume that $\hat{\pi}_{t+1}=\widetilde{\mathbb{E}}_{t} \pi_{t+1}$, where $\widetilde{\mathbb{E}}_{t}$ indicates the rational forecast given all information available to private agents at time $t$. By defining $u_{t}=$ $\beta\left(\widetilde{\mathbb{E}}_{t} \pi_{t+1}-\mathbb{E}_{t} \pi_{t+1}\right)$, we obtain the following aggregate supply relation:

$$
\pi_{t}=\beta \mathbb{E}_{t} \pi_{t+1}+\lambda x_{t}+u_{t}
$$

Evidently, $u_{t} \equiv 0$ in the New Keynesian model described above, whereas $u_{t}$ will contribute to inflation persistence in the case where private agents do not have full information about the central bank's inflation target.

We can obtain an analytic expression for the behavior of $u_{t}$ when aggregate demand is determined by the New Keynesian IS curve, the central bank follows a simplified interest rate reaction function (involving only the current one quarter inflation

${ }^{23}$ Alternative specifications of adaptive expectations have recently been analyzed by Ireland (2000) and Ball (2000). 
rate and the current output gap), and the inflation target $\pi_{t}^{*}$ is the sum of a random walk component $\pi_{p t}$ and a white noise component $\pi_{q t} \cdot{ }^{24}$ In this case, we find that $u_{t}$ follows the process

$$
u_{t}=\left(1-\kappa_{g}\right) u_{t-1}+\left(1-\kappa_{g}\right) \phi \varepsilon_{p t}
$$

where $\phi<0, \kappa_{g}$ is the Kalman gain coefficient in the updating equation (24) for $\widetilde{\mathbb{E}}_{t} \pi_{p t}$ that applies when $\rho_{p}=1$, and recalling that $\varepsilon_{p t}$ is the innovation in the persistent component of the inflation target. In the case of full information about the inflation target, the Kalman gain $\kappa_{g}=1$, and hence $u_{t}=0$ as in the New Keynesian model; in this case, inflation exhibits no persistence, and disinflation does not involve any output costs. In contrast, a lower signal-to-noise ratio regarding the inflation target (and hence lower $\kappa_{g}$ ) is associated with higher volatility and persistence of $u_{t}$, and this persistence passes through into the actual inflation process.

\section{Conclusions}

In this paper, we have formulated a DGE model with optimizing agents and staggered nominal contracts, in which private agents use optimal filtering to make inferences about the central bank's inflation target. We have shown that this model accounts quite well for several important features of the Volcker disinflation episode: a pronounced initial rise in the nominal interest rate, a sluggish decline in the inflation rate, a persistently negative output gap, and persistent inflation forecast errors. In this framework, inflation persistence is not an inherent characteristic of the model economy, but rather arises whenever agents must learn about shifts in the monetary policy regime.

To avoid a non-linear signal extraction problem, we have assumed that private agents have complete information about the specification and coefficients of the monetary policy rule, and that the inflation target itself is the only aspect of monetary policy that is not fully observed. As noted above, however, the appropriate characterization of Federal Reserve policy during the Volcker disinflation period continues to be somewhat contentious even after two decades, and hence was almost certainly not as transparent to market participants at the time. In future research, it would be interesting to allow for time variation in the policy rule coefficients and for a discrete probability of policy reversals. ${ }^{25}$ More generally, our analysis emphasizes the benefits of explicitly considering informational constraints faced by private agents as well as by the central bank, and we believe that such an approach may be fruitful in explaining inflation and output persistence in other periods. ${ }^{26}$

\footnotetext{
${ }^{24}$ That is, $x_{t}=\widetilde{\mathbb{E}}_{t} x_{t+1}-\frac{1}{\sigma}\left(i_{t}-\widetilde{\mathbb{E}}_{t} \pi_{t+1}-r_{t}^{*}\right)$ and $i_{t}=\bar{r}+\pi_{t}+\gamma_{\pi}\left(\pi_{t}-\pi_{t}^{*}\right)+\gamma_{x} x_{t}$, where $\mathrm{x}_{t}$ denotes the output gap.

${ }^{25}$ Fuhrer and Hooker (1993) analyzed a structural macroeconometric model in which agents face uncertainty about the coefficients of the monetary policy rule, but not about the inflation target.

${ }^{26}$ Regarding informational constraints faced by the central bank, Orphanides (2000) has recently emphasized the extent to which large and persistent output gap mismeasurements may account for Federal Reserve behavior during the 1970s. For analysis of optimal disinflationary paths, see Ireland
} 
Finally, we have proceeded under the assumption that private agents behave optimally, but have not directly considered the optimization problem of the central bank itself. In future research, it will be useful to give explicit consideration to the incentives and commitment mechanisms of the central bank, and to investigate various approaches for enhancing the credibility and transparency of the monetary policy regime. ${ }^{27}$

\section{References}

Ball, Laurence. 1994. Credible Disinflation with Staggered Price-Setting. American Economic Review 84, 282-289.

Ball, Laurence. 1994b. What Determines the Sacrifice Ratio? In: N.G. Mankiw (ed.), Monetary Policy. University of Chicago Press, Chicago, 155-182.

Ball, Laurence. 1995. Disinflation and Imperfect Credibility. Journal of Monetary Economics 35, 5-24.

Ball, Laurence. 1995b. Time-Consistent Policy and Persistent Changes in Inflation. Journal of Monetary Economics 36, 329-350.

Ball, Laurence. 2000. Near-Rationality and Inflation in Two Monetary Regimes. National Bureau of Economic Research Working Paper 7988.

Bernanke, Ben, Thomas Laubach, Frederic Mishkin, and Adam Posen. 1999. Inflation Targeting: Lessons from the International Experience. Princeton University Press, Princeton, NJ.

Blanchard, Olivier and Charles Kahn. 1980. The Solution of Linear Difference Models under Rational Expectations. Econometrica 48, 1305-1311.

Blinder, Alan. 1987. Hard Heads, Soft Hearts: Tough-Minded Economics for a Just Society. Addison Welsey, New York.

Bomfim, Antulio, Robert Tetlow, Peter von zur Muehlen, and John Williams. 1997. Expectations, Learning, and the Costs of Disinflation: Experiments using the FRB/US Model. Finance and Economics Discussion Series no. 1997-42. Washington, D.C.: Board of Governors of the Federal Reserve System.

Brunner, Karl. 1987. Has Monetarism Failed? In: Dorn, James and Anna Schwartz (eds.), The Search for Stable Money: Essays on Monetary Reform. University of Chicago Press, Chicago and London, 163-199.

Brunner, Karl, Alex Cukierman and Allan Meltzer. 1980. Stagflation, Persistent Unemployment and the Permanence of Economic Shocks. Journal of Monetary Economics 6, 467-92.

(1997), Orphanides and Wilcox (1997), and Orphanides et al. (1998).

${ }^{27}$ For analysis of the time-consistency issue as well as incentive and commitment mechanisms for monetary policy, see Ball (1995b) and Svensson and Woodford (1999). For discussion of practical issues related to credibility and transparency of inflation targeting regimes, see Taylor (1982), McCallum (1995), and Bernanke et al. (1999). 
Buiter, Willem and Ian Jewett. 1989. Staggered Wage Setting and Relative Wage Rigidities: Variations on a Theme of Taylor. Reprinted in: Willem Buiter (ed.), Macroeconomic Theory and Stabilization Policy. University of Michigan Press, Ann Arbor, 183-199.

Calvo, Guillermo. 1983. Staggered Prices in a Utility Maximizing Framework. Journal of Monetary Economics 12, 383-98.

Chari, V. V., Patrick Kehoe, and Ellen McGrattan. 2000. Sticky Price Models of the Business Cycle: Can the Contract Multiplier Solve the Persistence Problem? Econometrica, 68, 1151-79.

Christiano, Lawrence and Christopher Gust. 2000. The Expectations Trap Hypothesis. Federal Reserve Bank of Chicago Economic Perspectives 24, 21-39.

Clarida, Richard, Jordi Gali, and Mark Gertler. 1999. The Science of Monetary Policy: A New Keynesian Perspective. Journal of Economic Literature 37, 16611707.

Clarida, Richard, Jordi Gali, and Mark Gertler. 2000. Monetary Policy Rules and Macroeconomic Stability: Evidence and Some Theory. Quarterly Journal of Economics 115, 147-180.

Cogley, Timothy and Thomas Sargent. 2000. Evolving Post-World War II U.S. Inflation Dynamics. Manuscript.

Cook, Thomas. 1989. Determinants of the Federal Funds Rate, 1979-82. Federal Reserve Bank of Richmond Economic Review 75, 3-19.

Cummins, Jason, and Kevin Haskett, and Steven Oliner. 1987. Investment Behavior, Observable Expectations, and Internal Funds. Manuscript, New York University.

Eberly, Janice. 1997. International Evidence on Investment and Fundamentals. European Economic Review 41, 1055-78.

Edge, Rochelle. 2000. The Equivalence of Wage and Price Staggering in Monetary Business Cycle Models. International Finance Discussion Papers, no. 672. Washington, D.C.: Board of Governors of the Federal Reserve System.

Edge, Rochelle. 2000b. Time-to-Build, Time-to-Plan, Habit-Persistence, and the Liquidity Effect. International Finance Discussion Papers, no. 673. Washington, D.C.: Board of Governors of the Federal Reserve System.

Erceg, Christopher. 1997. Nominal Wage Rigidities and the Propagation of Monetary Disturbances. International Finance Discussion Papers, no. 590. Washington, D.C.: Board of Governors of the Federal Reserve System.

Erceg, Christopher, Dale Henderson, and Andrew Levin. 2000. Optimal Monetary Policy with Staggered Wage and Price Contracts. Journal of Monetary Economics 46, 281-313.

Evans, Martin and Paul Wachtel. 1993. Inflation Regimes and the Sources of Inflation Uncertainty. Journal of Money, Credit, and Banking 25, 475-511. 
Friedman, Milton. 1985. Monetarism in Rhetoric and Practice. In: Ando, Albert, et al. (eds), Monetary Policy in Our Times: Proceedings of the First International Conference Held by the Institute for Monetary and Economic Studies of the Bank of Japan. MIT Press, Cambridge, Massachusetts and London, 15-28.

Fuhrer, Jeffrey and Mark Hooker. 1993. Learning about Monetary Regime Shifts in an Overlapping Wage Contract Model. Journal of Economic Dynamics and Control $17,531-53$.

Fuhrer, Jeffrey, and George Moore. 1995. Inflation Persistence. Quarterly Journal of Economics 110, 127-159.

Gertler, Mark. 1982. Imperfect Information and Wage Inertia in the Business Cycle. Journal of Political Economy 5, 967-987.

Goodfriend, Marvin. 1991. Interest Rates and the Conduct of Monetary Policy. Carnegie-Rochester Series on Public Policy 34, 7-30.

Goodfriend, Marvin. 1993. Interest Rate Policy and the Inflation Scare Problem, 1979-92. Federal Reserve Bank of Richmond Economic Quarterly 79, no. 4, 1-24.

Goodfriend, Marvin. 1997. Monetary Policy Comes of Age: A 20th Century Odyssey. Federal Reserve Bank of Richmond Economic Quarterly 83, no. 4, 1-24.

Huh, Chan and Kevin Lansing. 2000. Expectations, Credibility, and Disinflation in a Small Macroeconomic Model. Journal of Economics and Business 52, issue 1-2, $51-86$.

Ireland, Peter. 1995. Optimal Disinflationary Paths. Journal of Economic Dynamics and Control 19, 1429-48.

Ireland, Peter. 1997. Stopping Inflations, Big and Small. Journal of Money, Credit, and Banking 29, 759-75.

Ireland, Peter. 2000. Expectations, Credibility, and Time-Consistent Monetary Policy. Macroeconomic Dynamics 4, 448-466.

Kim, Jinill. 2000. Constructing and Estimating a Realistic Optimizing Model of Monetary Policy. Journal of Monetary Economics 45, 329-359.

King, Robert and Alexander Wolman. 1999. What Should the Monetary Authority Do When Prices are Sticky? In: Taylor, J. (Ed.), Monetary Policy Rules. University of Chicago Press: Chicago, 349-398.

Levin, Andrew. 1989. The Theoretical and Empirical Relevance of Staggered Wage Contract Models. Ph.D. dissertation, Stanford University.

Lucas, Deborah. 1985. Staggered Price Contracts with Monopolistic Competition. Ph.D. dissertation, University of Chicago.

Mankiw, N. Gregory. 1991. Macroeconomics. Worth, New York.

McCallum, Bennett. 1995. Two Fallacies Concering Central Bank Independence. American Economic Review 85, 207-211. 
Melton, William. 1985. Inside the Fed: Making Monetary Policy. Dow Jones-Irwin: Homewood, Illinois.

OECD Economic Outlook. Organization for Economic Co-operation and Development: Paris and Washington, D.C. Various issues.

Orphanides, Athanasios. 2000. Activist Stabilization Policy and Inflation: The Taylor Rule in the 1970s. Finance and Economics Discussion Paper no. 2000-13. Washington, D.C.: Board of Governors of the Federal Reserve System.

Orphanides, Athanasios, David Small, Volker Wieland, and David Wilcox. 1997. A Quantitative Exploration of the Opportunistic Approach to Disinflation. Finance and Economics Discussion Paper no. 1997-36. Washington, D.C.: Board of Governors of the Federal Reserve System.

Orphanides, Athanasios, and Volker Wieland. 1998. Price Stability and Monetary Policy Effectiveness when Nominal Interest Rates are Bounded at Zero. Finance and Economics Discussion Paper no. 98-35. Washington, D.C.: Board of Governors of the Federal Reserve System.

Orphanides, Athanasios and David Wilcox. 1996. The Opportunistic Approach to Disinflation. Finance and Economics Discussion Paper no. 1996-24. Washington, D.C.: Board of Governors of the Federal Reserve System.

Roberts, John M. 1997. Is Inflation Sticky? Journal of Monetary Economics 39, 173-196.

Roberts, John M. 1998. Inflation Expectations and the Transmission of Monetary Policy. Finance and Economics Discussion Paper no. 98-43. Washington, D.C.: Board of Governors of the Federal Reserve System.

Roberts, John M. 2001. How Well Does the New Keynesian Sticky-Price Model Fit the Data? Finance and Economics Discussion Paper no. 2001-13. Washington, D.C.: Board of Governors of the Federal Reserve System.

Rotemberg, Julio. 1996. Prices, Output, and Hours: An Empirical Analysis Based on a Sticky Price Model. Journal of Monetary Economics 37, 505-533.

Rotemberg, Julio and Michael Woodford. 1997. An Optimization-Based Econometric Framework for the Evaluation of Monetary Policy. In: Bernanke, B.S, Rotemberg, J.J. (Eds.), NBER Macroeconomics Annual 1997. MIT Press: Cambridge, 297-346.

Sachs, Jeffrey. 1985. The Dollar and the Policy Mix: 1985. Brookings Papers on Economic Activity 0, issue 1, 117-185.

Shapiro, Matthew. 1986. The Dynamic Demand for Capital and Labor. Quarterly Journal of Economics 101, 513-542.

Sargent, Thomas. 1986. Stopping Moderate Inflations: The Methods of Poincare and Thatcher. Chapter 4 of Rational Expectations and Inflation. Harper and Row: New York, 110-157. 
Svensson, Lars and Michael Woodford. 1999. Implementing Optimal Policy through Inflation-Forecast Targeting. Manuscript, Princeton University.

Taylor, John. 1980. Aggregate Dynamics and Staggered Contracts. Journal of Political Economy 88, 1-24.

Taylor, John. 1982. Establishing Credibility: A Rational Expectations Viewpoint. American Economic Review 72, 81-85.

Taylor, John. 1983. Union Wage Settlements during a Disinflation. American Economic Review 73, 981-983.

Taylor, John. 2000. Low Inflation, Pass-Through, and the Pricing Power of Firms. European Economic Review 44, 1389-1408.

Yun, Tack. 1996. Nominal Price Rigidity, Money Supply Endogeneity, and Business Cycles. Journal of Monetary Economics 37, 345-370. 
Figure 1. U.S. GDP Price Deflator Inflation Rate

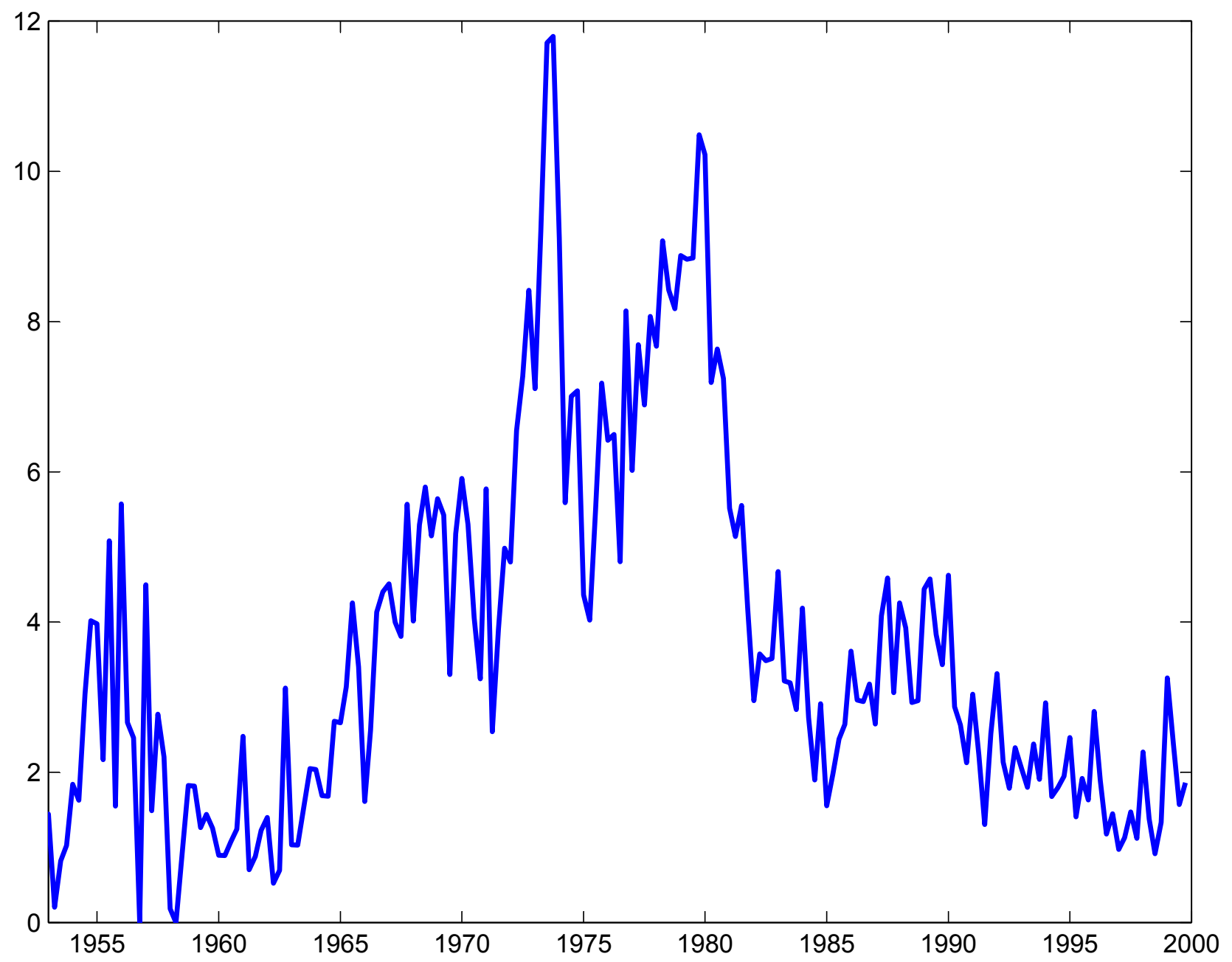


Key U.S. Macroeconomic Indicators under Volker: 1979-1985

Figure 2. Federal Funds Rate

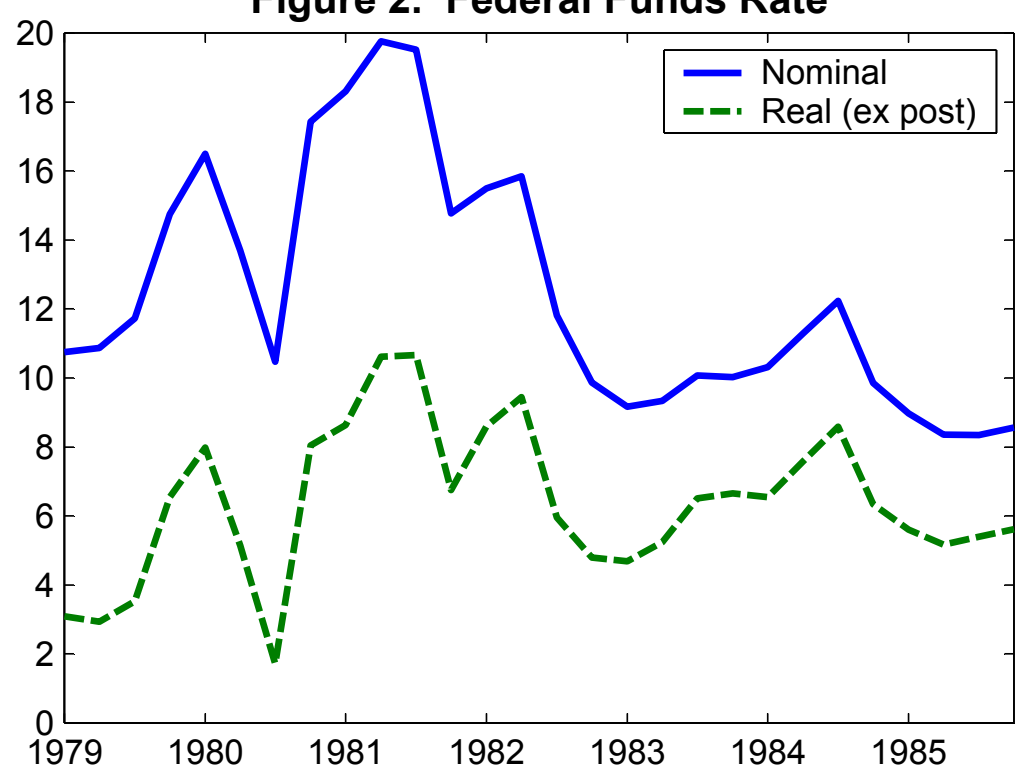

Figure 4: Short-term Expected Inflation

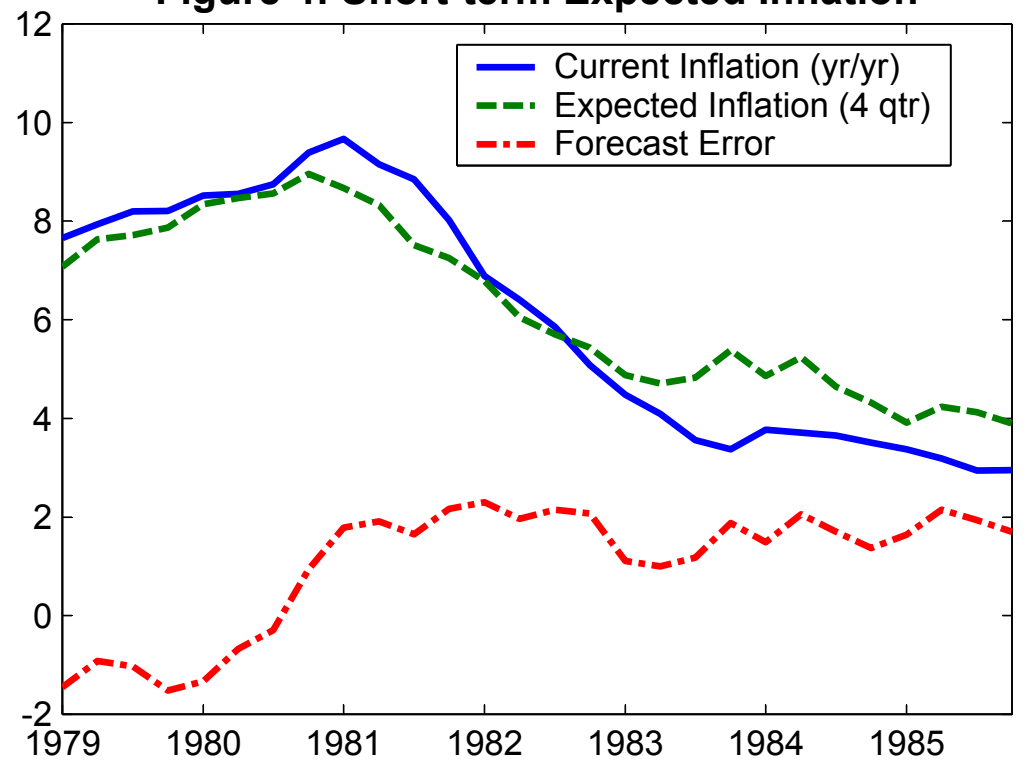

Figure 3. Output Gap (OECD)

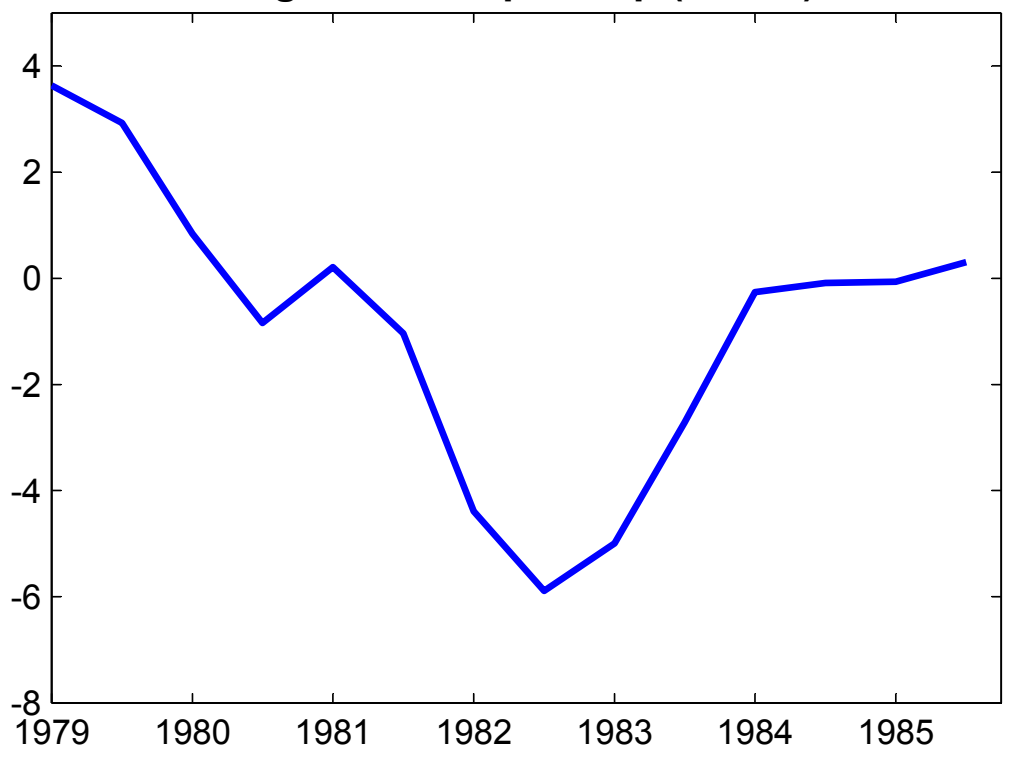

Figure 5. Long-term Expected Inflation

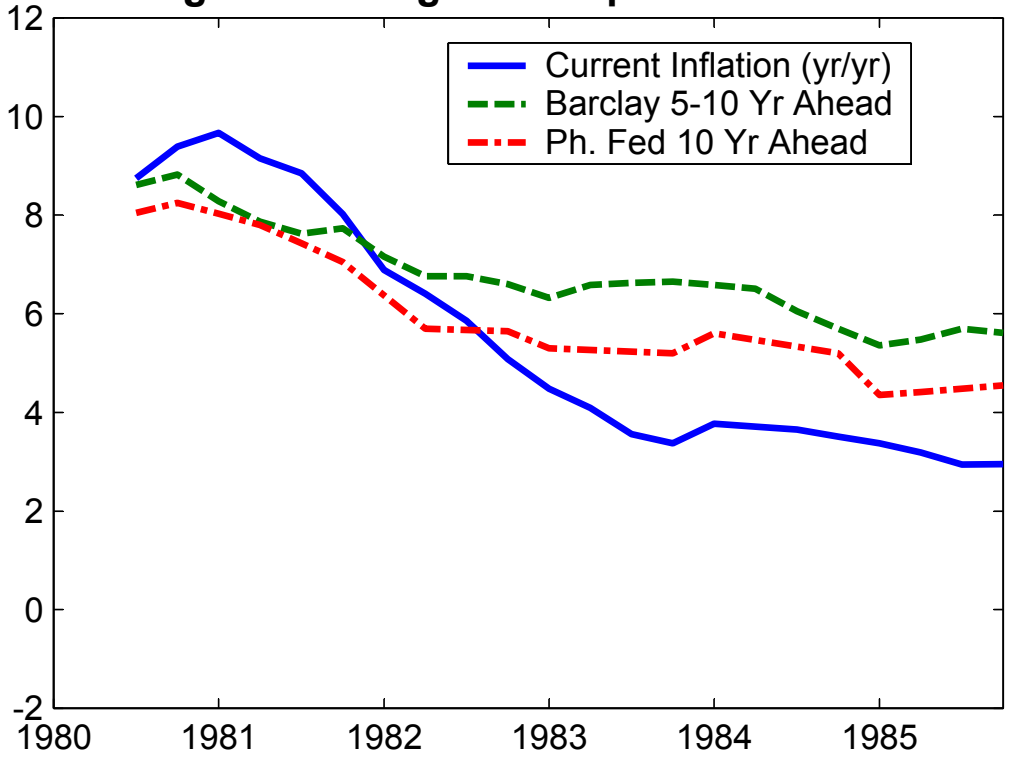




\section{Disinflation Episodes in the United Kingdom and Canada}
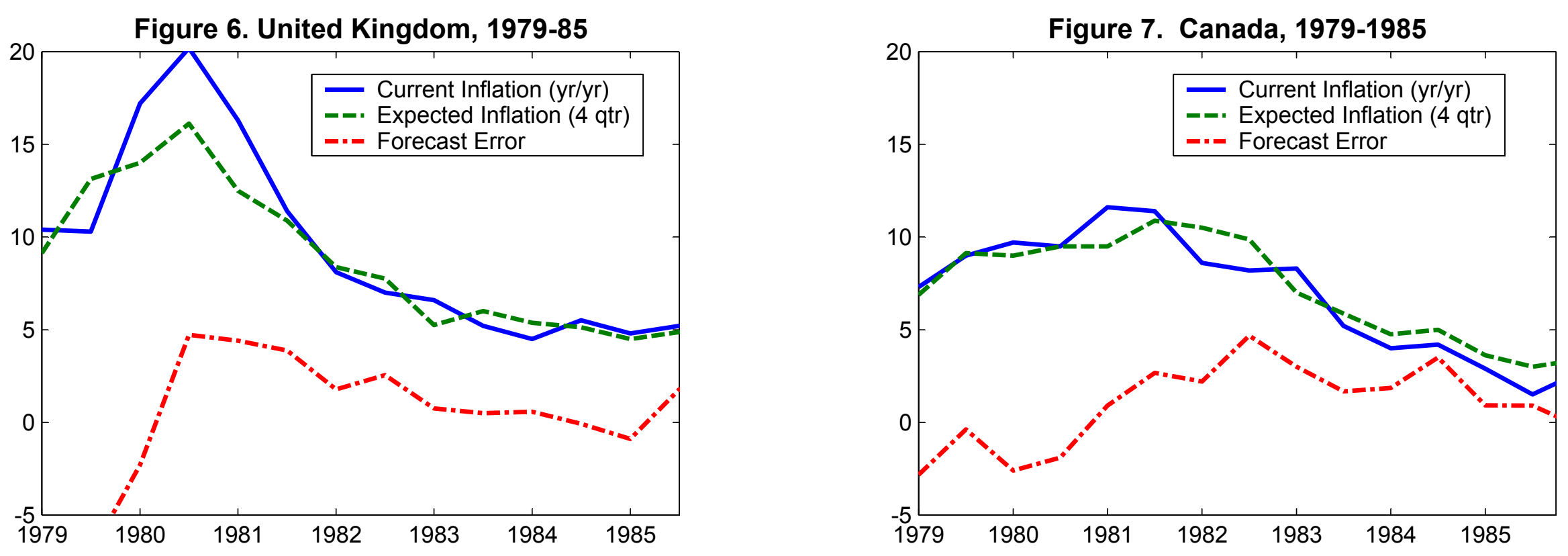
Figure 8. Actual and Fitted Federal Funds Rate

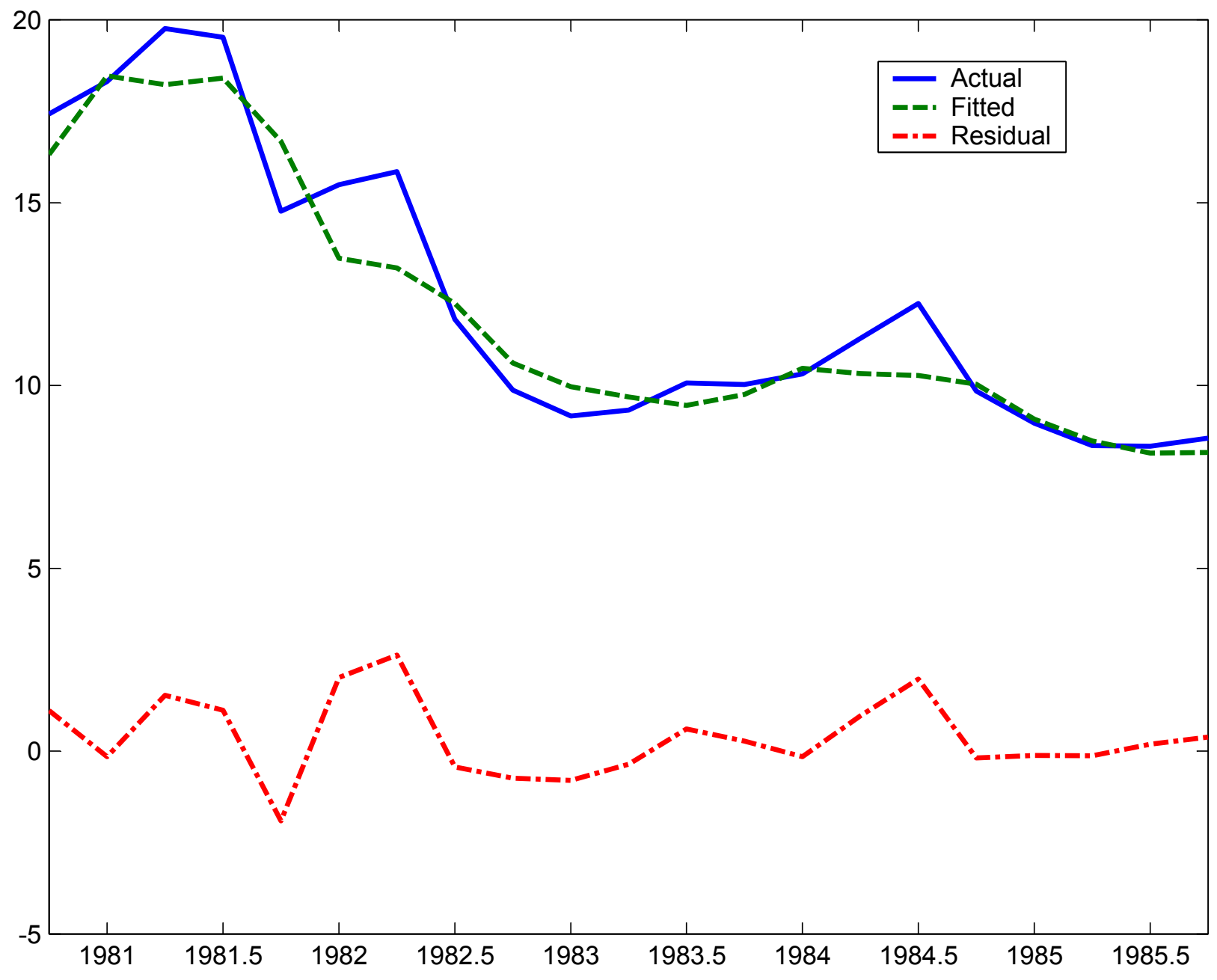


Figure 9. Full Information vs. Imperfect Observability of the Inflation Target
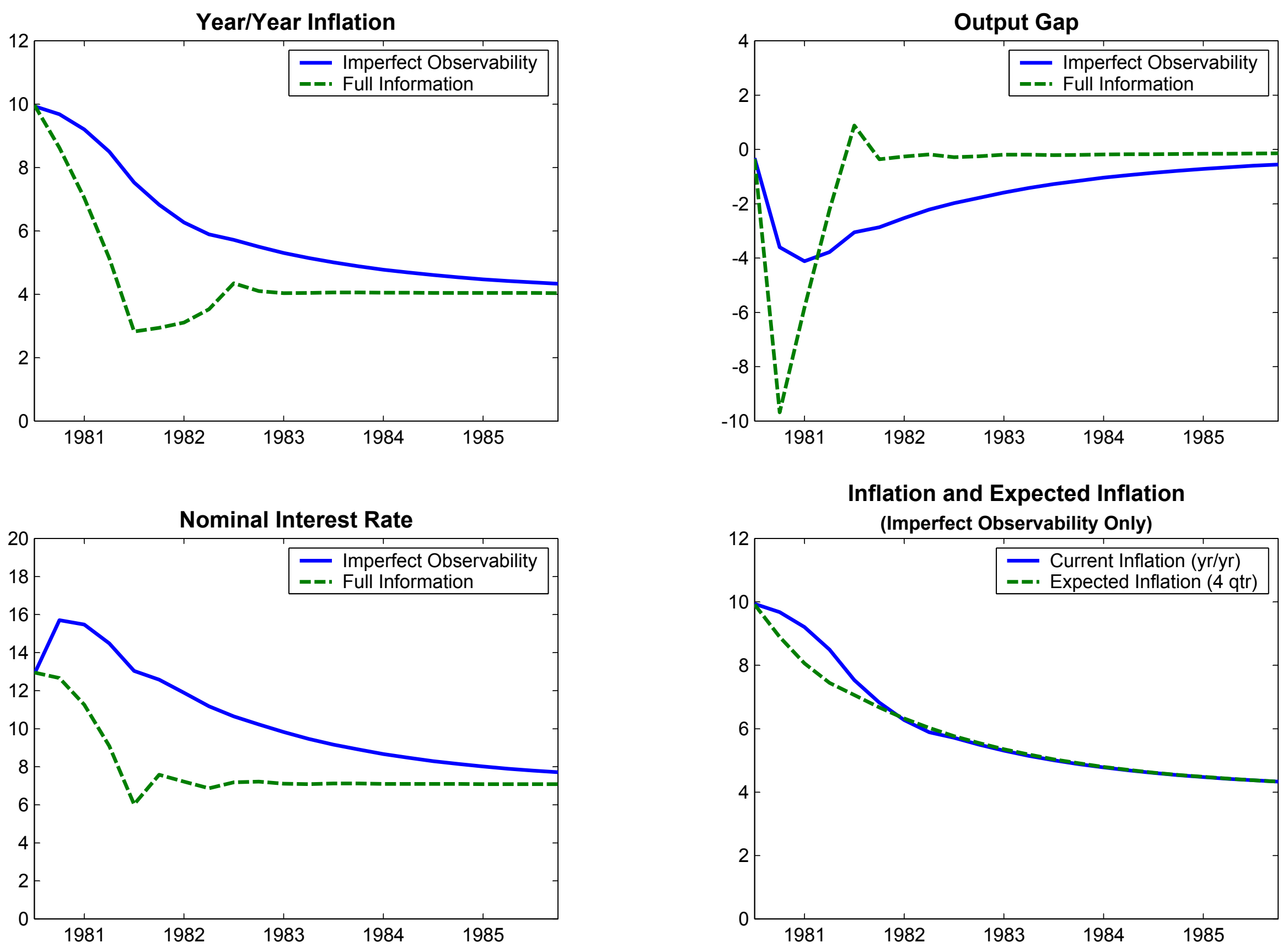
Figure 10. Sensitivity Analysis

a. Expenditure Components (Baseline)

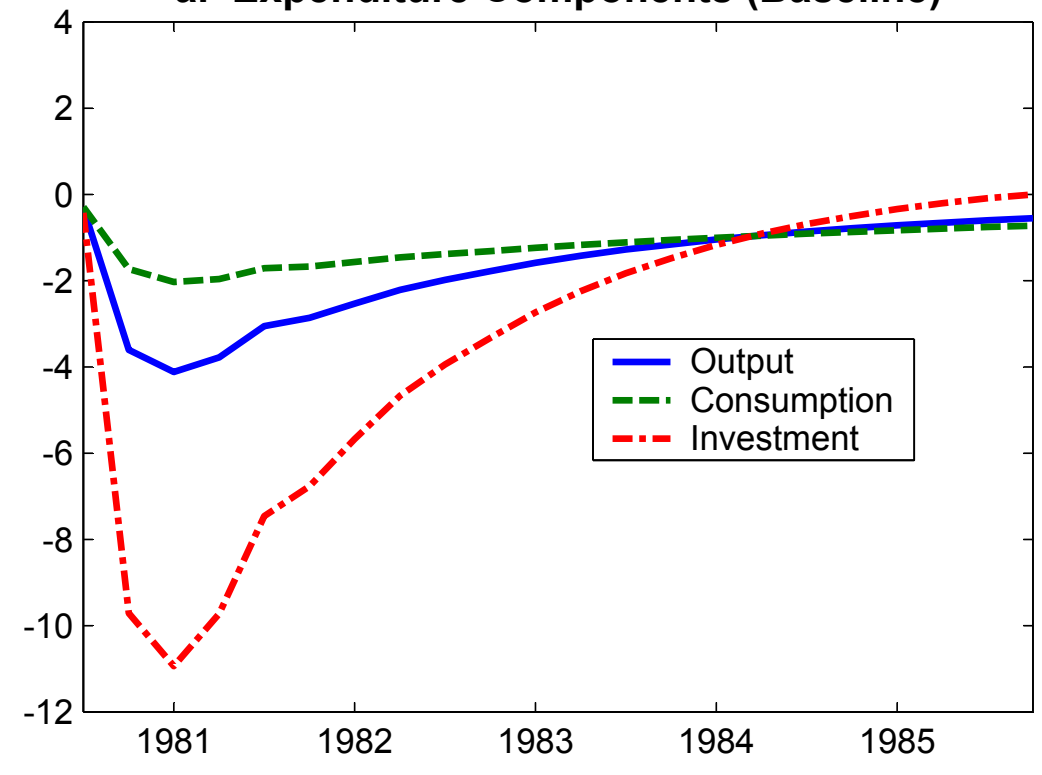

c. Output: Sticky vs. Flex. Wages

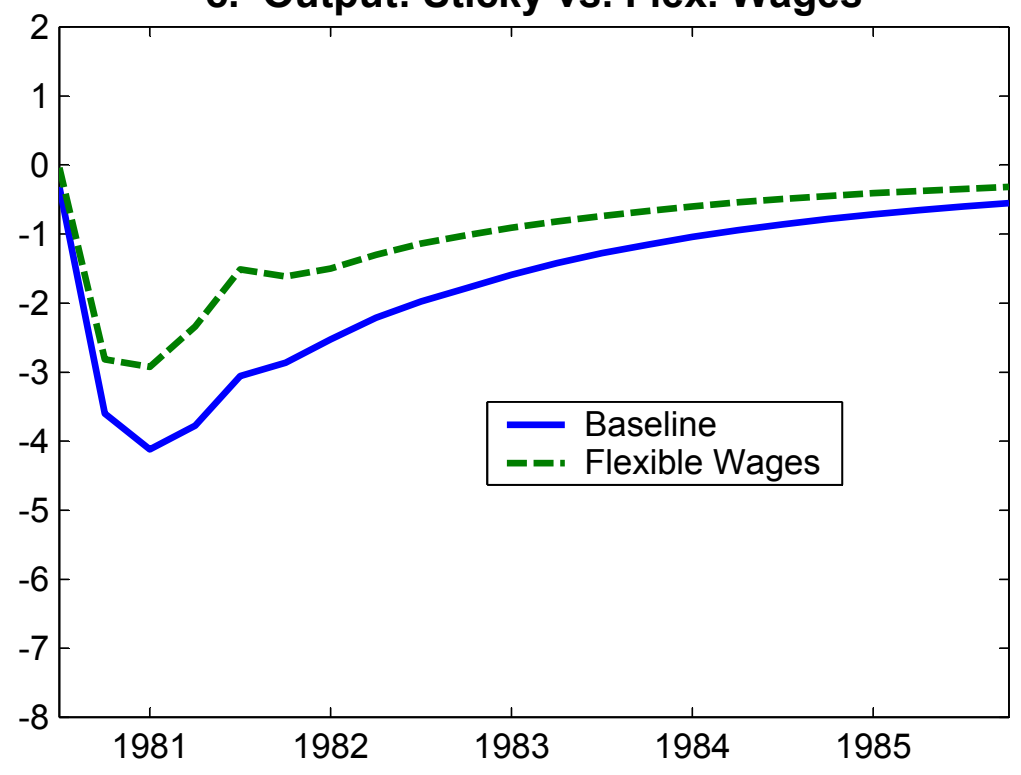

b. Output: Different Capital Adjustment Costs

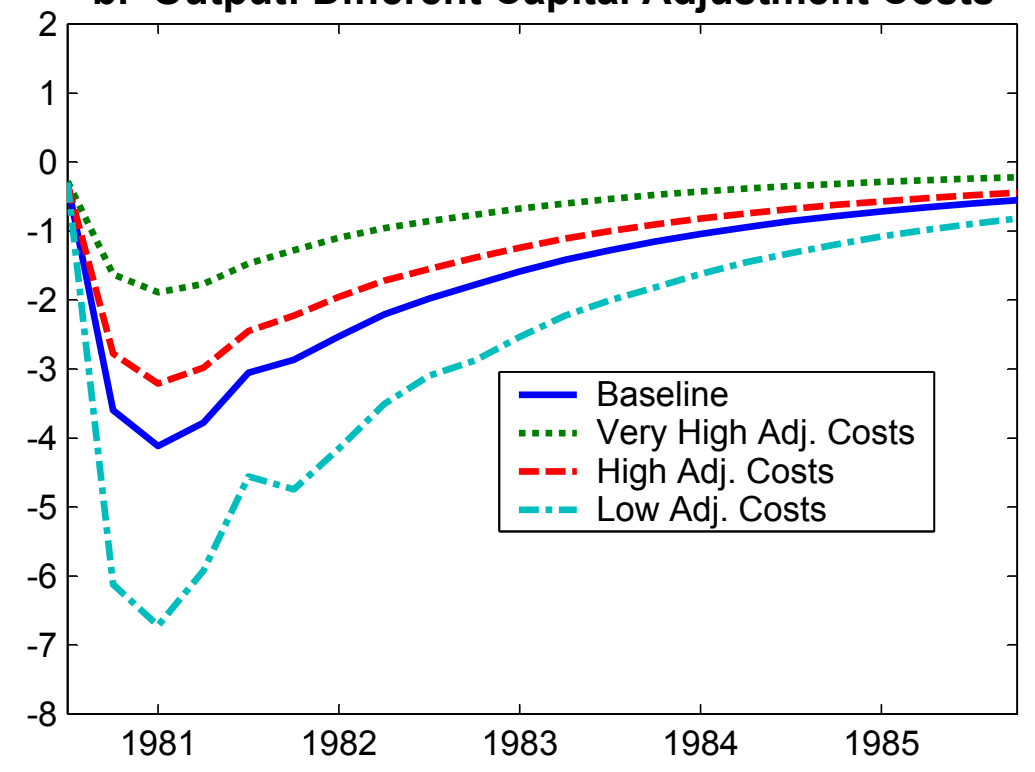

d. Output: Different Monetary Rule Parameters

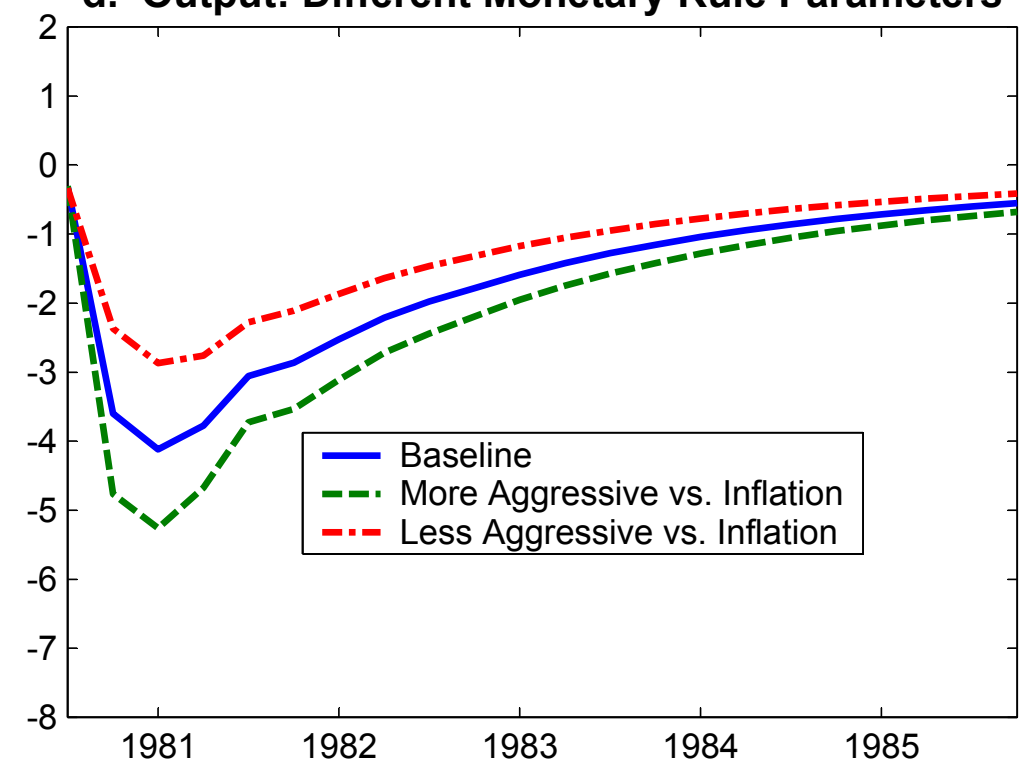




\section{Comparisons of Model Simulations with Data}

Figure 11. Inflation Forecast Errors

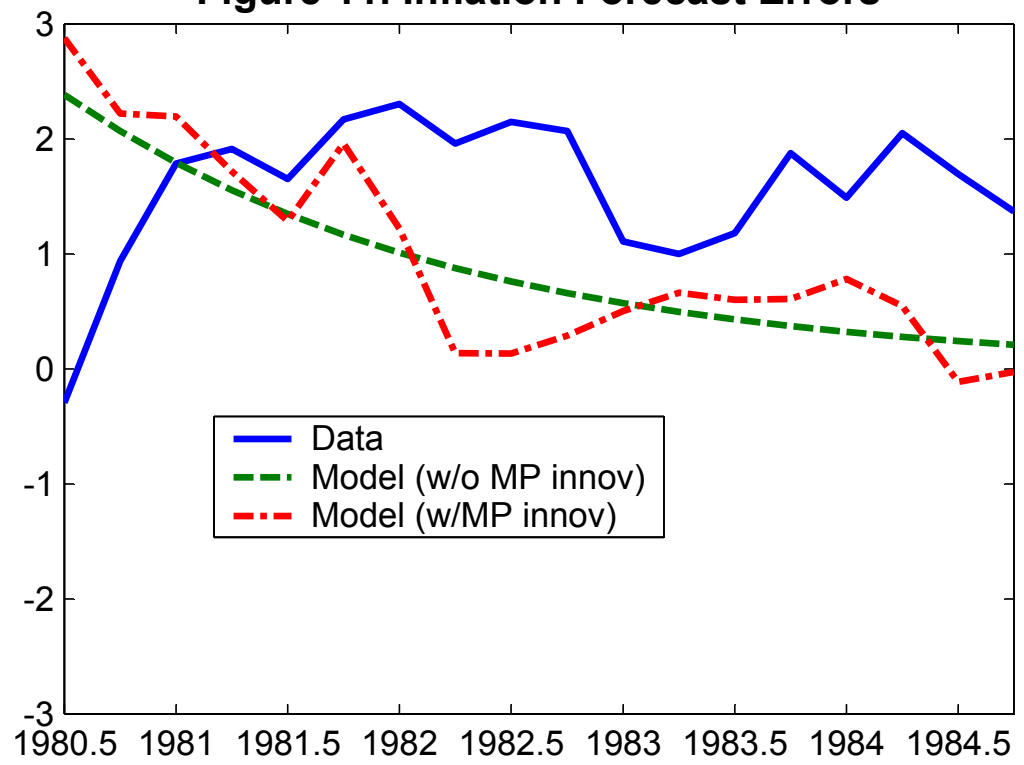

Figure 12. Output Gap

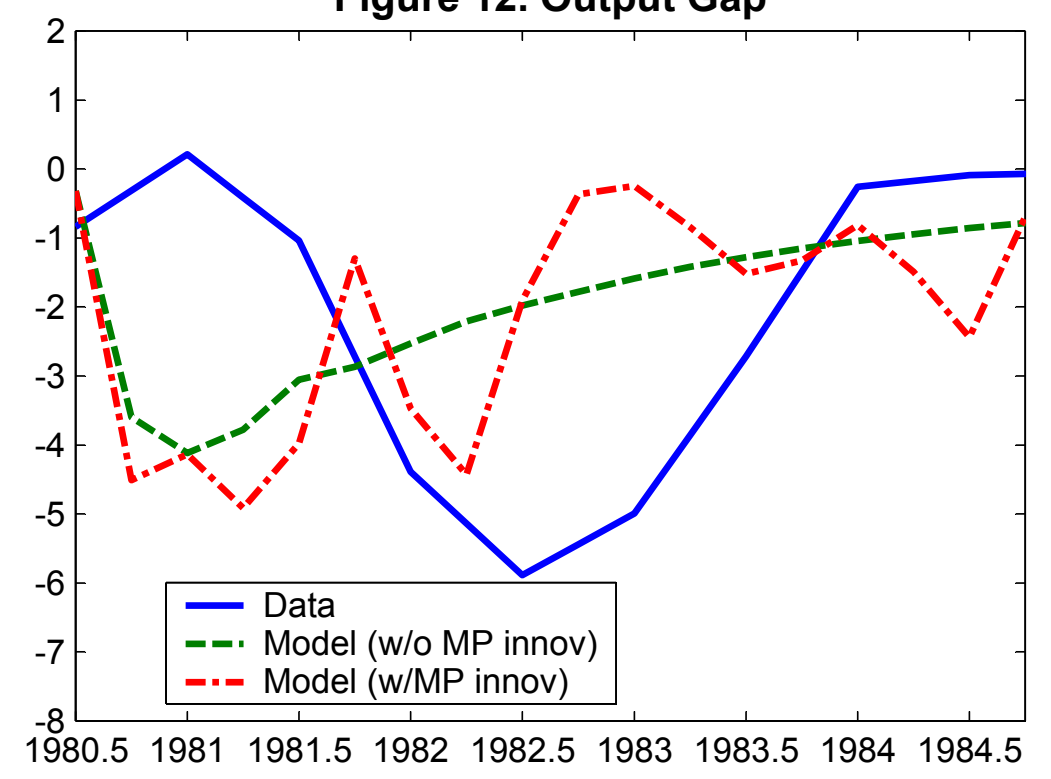

